\title{
GOBERNADORES DE MELILLA EN EL ÚLTIMO TERCIO DEL SIGLO XVII
}

\author{
Juan Corbalán de Celis y Durán \\ Académico Correspondiente de la RAC Valenciana \\ jcorbalandecelis@gmail.com
}

\begin{abstract}
Resumen: Se aporta una serie de noticias biográficas de los gobernadores de la Plaza de Melilla en el último tercio del siglo XVII, noticias que resultan algunas de ellas desconocidas o poco conocidas. A través de estas notas, en las palabras, hechos y circunstancias de estos personajes se vislumbra la triste situación por la que atraviesa España a lo largo de estos años, y como consecuencia de ello el abandono en que se encontraba esta Plaza. Noticias y datos que se dan con el intento de contribuir, aunque sea ligeramente, al conocimiento de esa historia pequeña que nos ayuda a ir comprendiendo el hecho local y social de esta población.
\end{abstract}

Palabras Clave: Gobernadores, Melilla, Genealogía, Siglo XVII

Abstract: A collection of biographic references about the Governors of Melilla in the last third of the XVII century is provided, some of them are mostly unknown. Going through this notes, words, facts and circumstances of this figures, gives a glimpse of the depressed situation being experienced in Spain at that time. And as a result, the situation of abandonment suffered by the settlement of Melilla. This news and realities are explained to contribute with the understanding of the local history, as well as the local and social facts.

Keywords: Governors, Melilla, Genealogy, XVII century

En los últimos treinta años del siglo XVII, gobernaron la plaza de Melilla un total de nueve personajes, de los cuales vamos a intentar trazar una semblanza biográfica y genealógica con el ánimo de ampliar las escasas noticias que tenemos sobre los mismos, de precisar las fuentes de donde surgen esas noticias sobre Melilla relacionadas con ellos, de corregir o aclarar algunos hechos y fechas, de acotar en lo posible los años de sus respectivos mandatos, todo ello con el modesto intento de contribuir al conocimiento de esta población a través de su historia pequeña, presentado a manera de prosopografía, herramienta metodológica de indudable utilidad en los estudios históricos, que nos va aportar conocimientos 
sociológicos de esta época a través de sus individuos.

Se ha tratado de evitar en estas notas el presentar los datos sobre estos individuos como una sucesión de hechos trágicos y sangrientos, propósito un tanto arduo y dificultoso, ya que las noticias y fechas recogidas a través de los años, y que han llegado hasta nosotros, están casi siempre relacionadas con dichos hechos. Se trataba de mostrar el heroísmo de estos personajes en servicio de la corona, y el duro vivir en estas fronteras, o en aquellos lejanos reinos al otro lado del mar, sucesos y circunstancias que se pretendían resaltar con esas noticias, para que sirviesen de ejemplo a seguir por otros servidores, a la vez que exponente, a través de ellos, de la grandeza de la monarquía a la que servían. Así mismo las relaciones de servicios prestados que ellos presentaban, giraban igualmente sobre hechos o acciones de armas, con los que intentaban señalar sus esfuerzos y fatigas en servicio de dicha corona.

Se van a aportar una serie de datos desconocidos, o poco conocidos, que servirán para ampliar el conocimiento sobre algunos de estos personajes que vivieron en la Plaza de Melilla, para tratar de acercarnos a través de ellos y de sus "servicios militares", a esa intrahistoria que nos ayuda a completar la historia social de esos lugares donde estuvieron. Se darán también algunos datos novedosos, o se ampliarán los ya conocidos sobre los distintos sitios y vicisitudes de la plaza durante estos años, y sobre las obras de defensa que se acometieron, casi todas ellas de reparaciones o ampliaciones de las ya existentes. Sus constantes quejas y peticiones a la corona por las grandes carencias que sufre la Plaza, y a veces por desatenciones personales, casi siempre relacionadas con las pagas o cambios de destino, serán el reflejo de la triste situación por la que atraviesa España a lo largo de estos años.

La relación de gobernadores estudiados en esta ocasión (Corbalán de Celis, 2014, 2015 y 2016), incluyendo algunos interinos, es la siguiente: Francisco Osorio de Astorga (1669-1672), Diego de Arce (1672-1674), Pedro Moreo (1674-1675), José de Frías (1675-1679), Diego Toscano de Brito (1680-1682), Diego Pacheco de Arce (16821687), Francisco López Moreno (1687-1687), Bernabé Ramos de Miranda (1687-1692), Antonio de Zúñiga y de la Cerda (1692-1697) y Domingo de Canal y Soldevila (1697-1703). 


\section{A manera de introducción}

En el último tercio del siglo XVII la llegada al poder de la dinastía Alauita, va a producir un cambio político en la zona, que acabará con el relativo periodo de paz que se disfrutaba en los llamados presidios africanos. El nuevo sultán Muley Ismael, que ha heredado un país díscolo, fragmentado en tribus, va a centrar sus esfuerzos en consolidar el incipiente reino de Marruecos y desligarse de la sujeción al Imperio de Constantinopla, centrando sus esfuerzos, en los primeros años, en deshacerse de su rebelde sobrino Muley Ahmed que le disputaba el trono.

La Gaceta de Madrid de esos años recogía estos acontecimientos y así en julio de 1677 publicaba, que por las últimas noticias que se tenían de Berbería se sabía que el sultán ya había vencido a su sobrino, que se le había revelado junto con la ciudad de Marruecos, la cual había recobrado después de tres años de sitio y que éste, con la poca gente que le había querido seguir, se había refugiado 50 leguas adentro, en una zona muy fértil pero poblada de Alarbes, la gente más bárbara de aquellos parajes. Entró el vencedor en dicha ciudad de Marruecos con toda la ostentación que pudo, mermada después de tan larga y costosa guerra, restableciendo el gobierno y reparando con gran prisa los daños que habían sufrido sus fortificaciones. Empeñado en el ataque a Orán había enviado a su primogénito, gobernador de Fez, a Manuelias, nueve leguas al este de Melilla, con un potente ejército que pasaba a reforzar las operaciones contra Oran. Añadía la gaceta que Muley Ismael, actual rey de Marruecos y Fez, siempre en nuestra contra, era dueño de esta frontera y podía levantar en 24 horas un gran ejército, "sin embargo estamos con los buenos alientos que nos infunde la providencia de Su Majestad, y el cuidado de su Alteza, con que trabaja nuestro gobernador y todo este Presidio alegremente en apercibirse para lo que pudiere suceder" (Gaceta, 1677, 17 agosto, p. 31)

Asentado en el trono, va a dirigir sus esfuerzos en desalojar a los extranjeros de las plazas que ocupan en el país, declarando una guerra santa de exterminio, objetivo que va lograr, en parte, a lo largo de su dilatado reinado. Dentro de esta política de recuperación, o más bien de incorporación a su reino de estas plazas, va a impulsar los ataques contra la de Melilla, empezando un sistemático asalto a sus fuertes exteriores, que de reducidas dimensiones, mal concebidos y alejados de las defensas de la plaza, van a ir siendo tomados y destruidos uno tras otro. En septiembre de 1678 tomaban el fuerte de San Lorenzo, en marzo de 1679 ante su inminente pérdida, se decide volar el de San 
Francisco, y a finales de este mismo año tomaban el de Santiago. En los siguientes años fueron construyendo y adelantado sus líneas de ataque alrededor de la plaza, que aunque alejadas del alcance de su artillería, iban ciñéndola poco a poco. En octubre de 1688 sufría Melilla un riguroso sitio, que se repetiría en marzo de 1692 y en años posteriores, siendo sitiada en 1696 durante catorce meses. [1]

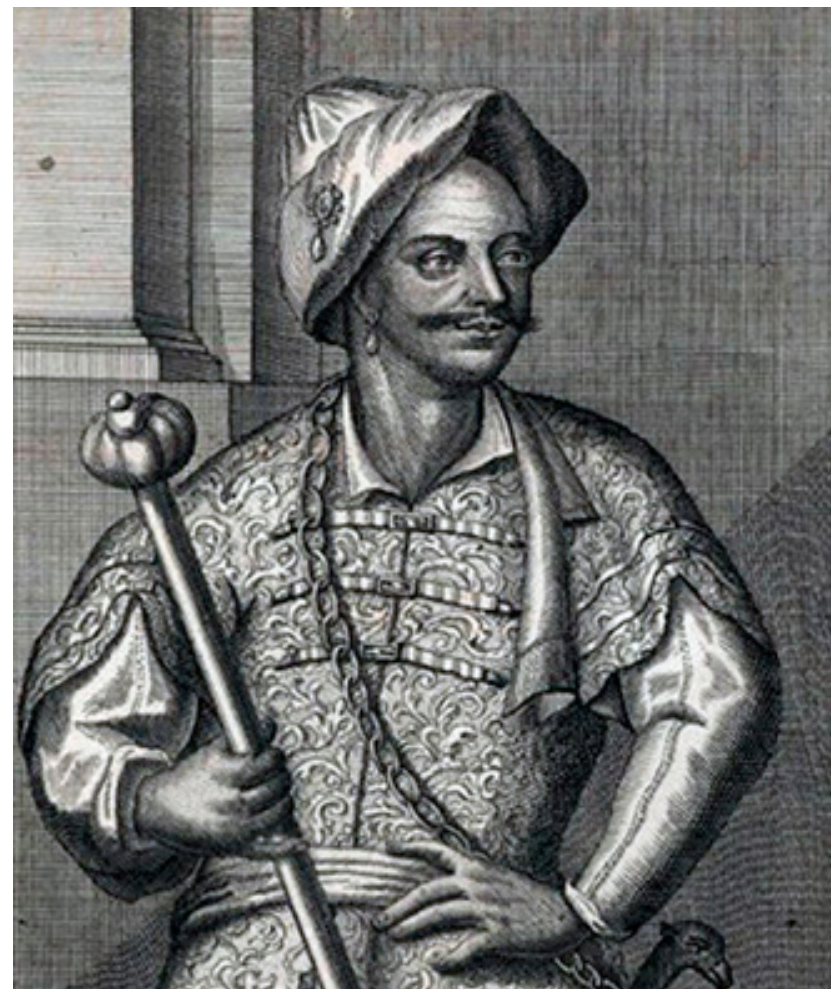

Fig. 1. El sultán Mulay Ismail.

\section{Francisco Osorio de Astorga}

El 7 de noviembre de 1667 en sustitución del maestre de campo don Luis Velázquez y Angulo, se nombraba a don Juan de Peñalosa y Estrada, capitán de caballos, gobernador interino de la Fuerza de Melilla $^{1}$, cargo que ocuparía hasta el 1 de junio de 1669 , en que se nombraba gobernador en propiedad al maestre de campo don Francisco Osorio de Astorga.

Malagueño, natural de la ciudad de Vélez, nace don Francisco en el seno de una hidalga familia radicada en el territorio de la Axarquía desde los tiempos de su conquista por el belmonteño Pedro Girón ${ }^{2}$. Hijo de don Lorenzo Gutiérrez Osorio de Astorga y de doña Magdalena Núñez de Aguilera $^{3}$, llegaba a Melilla después de más de treinta años de servicios. Servicios que había iniciado en el año 1638 como jinete de la compañía de Guardias Viejas de Castilla del marqués de Modéjar, en la costa del reino de Granada, pasando en junio de 1642 a continuarlos en el ejército de Cataluña, comenzada ya la guerra de Secesión.

El 13 de junio de 1643, durante el sitio de Monzón, toma parte 
en la batalla que se da contra las tropas franco-catalanes del general La Motte. Dominadas Tortosa y Monzón se pasó a poner sitio a la ciudad de Lérida, bajo guarnición francesa al mando del conde de Harcourt, participando con su tercio, "el 15 de mayo de 1644, en el asalto que se dio a los fuertes y trincheras del enemigo mandados por el conde de Ancurt" 4. Acude mosieur de La Motta a socorrerla, siendo Osorio uno de los que más se señalaron peleando, "cuando los franceses volvieron a envestir para recobrar los fuertes y trincheras que acababan de tomar" (AGI, Indiferente, 121, N.114), consiguiendo destrozarlos, de donde salió con dos heridas, encuentro que sería decisivo para la toma de la ciudad. Recuperado de sus heridas, se incorpora a la compañía de don Juan Isidro Dotto, siendo cogido prisionero en una emboscada que les hizo el enemigo, pero habiéndose escapado de la prisión se reincorporó a su unidad, participando en agosto de 1645 en el reencuentro que tuvo la caballería de su majestad con la del francés, cerca del monasterio de las Avellanas, durante las operaciones que el general Totavila llevaba a cabo en el intento de socorrer a Balaguer.

E1 22 de enero de 1647 se le concedía licencia para levantar, como capitán, una compañía de infantería, la cual tenía ya formada a primero de marzo, embarcando con ella con destino a Tarragona, plaza que gobernaba entonces "el señor Francisco Tutavila”, general de artillería, participando con su compañía, a finales de octubre, en las dos salidas que hizo la guarnición para tratar de tomar Constantín, “donde procedió con valor, en particular el día que se abrió brecha al dicho Constantin, en que fue nombrado para entrar dentro con una manga de mosquetería, y estuvo peleando aquel día hasta que se le envió orden para que se retirase" (AGI, 122, N.50). Rechazado el asalto, el aviso de que llegaba a socorrerla el marqués de Marfin

Había empezado a servir en 1647. En junio de 1677 gobernaba la plaza del Peñón. AGI. Indiferente, 125, N.127.

Según declaraba su sobrino Blas Gutiérrez Osorio de Astorga, hijo de su hermana Micaela, estando para embarcarse hacia México acompañando a su tío, esta familia habia llegado a esas tierras malagueñas cuando la conquista de Archidona, pasando luego a Benamocarra y más tarde a Vélez. Archivo General de Indias (AGI). Contratación, 5440, N.2, R. 161.

3 Este matrimonio tuvo al menos tres hijos: Micaela, casada con su primo hermano, el capitán Pedro Varo de Osorio; Blas Gutiérrez Osorio, veedor general de la Costa y reino de Granada; y dicho don Francisco. Lorenzo fue alférez de infantería, "aventajado" en la guardia personal del capitán general de la Costa, alcaide del castillo de Vélez.

$4 \quad$ AGI. Indiferente, 122, N.50. 
con fuerzas muy superiores, hizo retirarse a Totavila (Peña y Farel, 1709). [2].

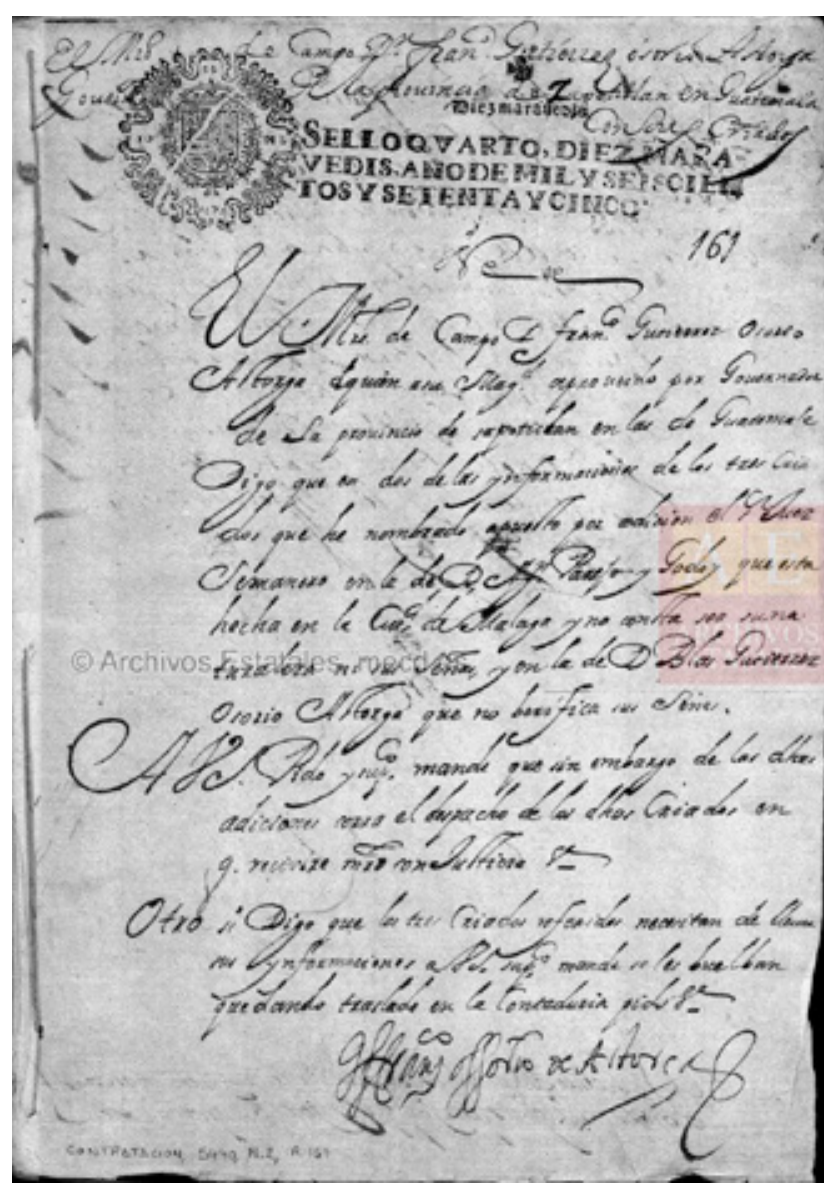

Fig. 2. Firma de Francisco Osorio Astorga. AGI Contratación5440, N.2, R.161.

Con las tropas del marqués de Mortara participa a finales de 1650 en el sitio y toma de Flix, siendo uno de los primeros que esguaçaron (vadearon) el río Ebro, y habiéndole nombrado el comisario general Aquil Nadal para que fuese con 12 caballos a su orden a reconocer la isla vadeó el río a nado de los caballos, y llegando donde el enemigo estaba emboscado y peleando con él, recibió muchas cargas de mosquetería, conque afirman que a riesgo de su vida dio lugar a que pasase el resto de nuestra caballería. Y habiéndose tomado dicho lugar y salido de el para quemar las barcas del Ebro el día que el enemigo vino a socorrer el castillo, el dicho comisario general, nombró a dicho don Francisco para que fuese con 30 caballos a su orden a entrar dentro del lugar, y hallando el paso cogido de la caballería del enemigo y la orilla del río coronada de migueletes, peleó con ellos (AGI., 122, N.50).

Tomaron luego la plaza de Miravet, y pasaron a poner asedio a la de Tortosa, a la que estuvieron batiendo hasta primeros de noviembre, y al no haberla podido socorrer el general Vendofme a pesar de su intento, capitularon los asediados el 4 de diciembre. (Gaspar Roig y Albi, 1675)

En 1651 se encuentra en el asedio de Barcelona, donde permanece hasta que es tomada la ciudad en octubre de 1652, participando al año 
siguiente, al mando de don José Pinós, general de la artillería de Granada, en la toma de la torre de los puentes de Orgañá y en el socorro y sitio de Gerona, que se encontraba sitiada por el francés, donde "llevando la a vanguardia con su Tercio, ejecutó todas las ordenes que se le dieron, y salió herido de un balazo en la mano derecha" (AGI, 122, N.50). El príncipe don Juan, que ha asistido en persona al socorro, informará posteriormente al rey que dicho don Francisco ha servido dieciséis años, que lo ha hecho con toda aprobación, habiéndose hallado en todas las ocasiones que se han ofrecido en el Ejercito de Cataluña, recibido heridas, y que particularmente en el reencuentro que se tuvo con el enemigo sobre Solsona y socorro de Berga se portó muy bien, y suplica el señor don Juan a SM le haga la merced que debe prometerse de su real grandeza. (AGI, 122, N.50).

En el sitio que se puso en 1655 a Solsona actuó, al mando de don Diego Caballero, "con mucho valor en los ataques y arrimar galerías, y el día que el enemigo vino a socorrer la plaza fue de los primeros que pelearon con él" (AGI, 122, N.50). Fracasado el intento, a finales de octubre pasaron al socorro de Berga donde "fue de los primeros que introdujeron el socorro en su castillo, peleando con el enemigo que ocupaba la montaña" (AGI, 122, N.50). Pasó después a Vic, plaza de la que había sido nombrado gobernador el general Pinós (Andreu Regens, 1655), "y estando de guarnición en dicha plaza, asistió a su fortificación con mucha vigilancia" (AGI, 122, N.50). [3]

Acabada la guerra de Cataluña, el 15 de febrero de 1658 el marqués de Mortara le concedía licencia para ir a la Corte con el fin de atender asuntos que requerían su presencia. Según declaraba, había servido en el ejército de Cataluña continuamente como capitán vivo y reformado y dos veces de sargento mayor, igualmente vivo y reformado. Al año siguiente, habiendo solicitado algún empleo en Indias, se le

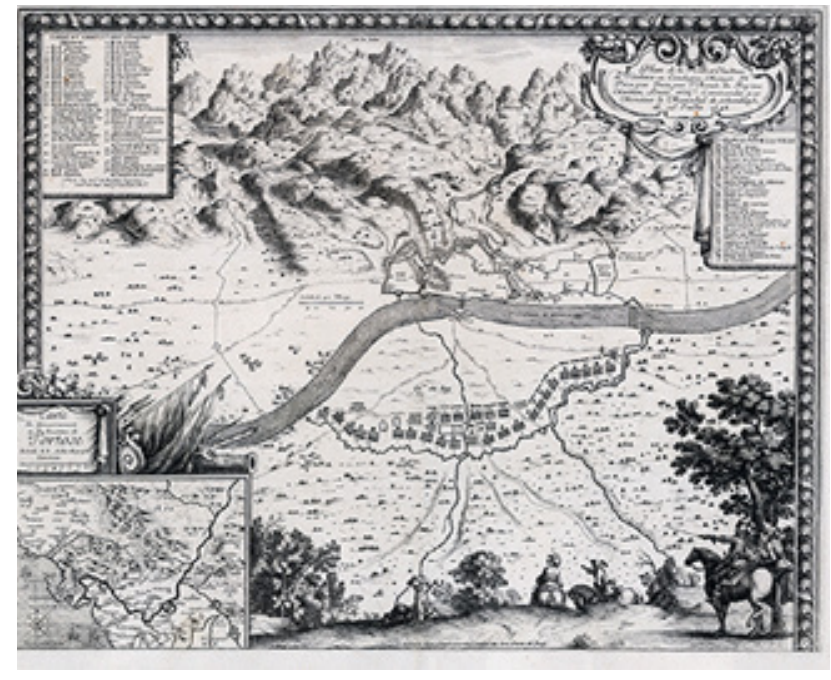

Fig.3. Castillo y villa de Tortosa. 
comisionaba para el gobierno de Tucumán y para el corregimiento de Tunja, en el Perú ${ }^{5}$, sin que al parecer saliese elegido para ninguno de ellos. Como continuase la guerra con Portugal, iniciada al tiempo de la de Cataluña, el 28 de abril de 1664 "su majestad le hacía merced del título de Maestre de Campo de Infantería Española del Tercio con que sirve a SM la ciudad de Granada en el Ejercito de Extremadura", (AGI, 121, N.114) sentando plaza el 15 de junio, "con 116 escudos de sueldo al mes y un escudo particular que goza sobre cualquier sueldo por haberse hallado en la recuperación de Barcelona" (AGI, 121, N.114). De guarnición en la plaza de Alcántara, hizo con su Tercio continuas salidas al campo enemigo, y en la sorpresa que se intentó sobre Rosmariñán, fue al mando de la infantería, "y tomo y ocupó el lugar y le quemó, hasta que el sargento general de batalla don Guillermo Casquear le ordenó retirarse" (AGI, Indiferente, 125, N.159) Pasó a Granada con orden de completar el Tercio para pasar con él al Ejercito de Cataluña, y cuando ya estaba listo para ello, se le ordenó detener la marcha, al haberse ajustado las paces con Francia.

Como habíamos señalado al principio, el 1 de junio de 1669 se la hacía merced de la Alcaidía de la Fuerça de Melilla. Su llegada va a coincidir con el cambio político que se está produciendo en la zona tras el acceso al poder de la dinastía Alauita, que va a finalizar el periodo de paz que se venía disfrutando en la plaza. El nuevo sultán Muley Ismael, que ha heredado un país fragmentado en tribus, va a centrar sus esfuerzos en consolidar el incipiente reino de Marruecos, y en desalojar a los extranjeros de las plazas que ocupan en el país, declarando una guerra santa de exterminio, objetivo que va lograr, en parte, a lo largo de su dilatado reinado.

A pesar de la profunda crisis por la que está pasando nuestra monarquía, que va a afectar todavía más al tradicional abandono en que se tiene a las plazas de África, principalmente por falta de presupuesto, el nuevo gobernador llega con la orden de reforzar las defensas de Melilla, refuerzo que acometerá con la reedificación de los fuertes de Santo Tomás, cerca de la cantera, y el de San Pedro, acometiendo también los trabajos de reparación del de San Francisco. El fuerte de Santo Tomás, construido en 1637, se encontraba arrasado, después de haber sido tomado por los moros el 24 de septiembre de 1667. Igualmente ocurría

Esta noticia aparece reseñada, con distinta letra, al margen de la relación de servicios que presentaba en julio de 1667. AGI. Indiferente, 121, N.114. 
con el de San Pedro, al que un desgraciado accidente había provocado su voladura el 7 de enero de 1670, recién llegado Osorio a la Plaza (Morales, 1995, pp.61-63). Estos fuertes construidos en ambos extremos de la vaguada que corría frente a la Plaza, oculta a la vista de los defensores, van a servir para controlar el amago en este sitio de tropas enemigas, y como primera línea de defensa de la Plaza, pero alejados de las defensas principales y sin apoyo directo, resultarán poco efectivos y dificultosos de sostener, como ya había quedado evidenciado y se repetiría apenas una década después.

El 11 de marzo de 1670 atacaron los moros el puesto de la Cantera, pero "con el manejo y buena disposición de las cortas tropas que sacó al Campo, dejando las más considerables en la guardia de la Plaza, rompió (a) los moros, obligándoles a retirarse, con mucha perdida de gente y caballos" (AGI, Indiferente, 125, N.159). Días después lo intentaron de nuevo por tres veces, esta vez sobre el fuerte de San Francisco, pero fueron rechazados obligándolos a retirarse con pérdida de mucha gente "y de los instrumentos que para esta ocasión llevaron" (AGI, 125, N.159), acción por la que el rey le daba las gracias en despacho de 16 de abril. [4]

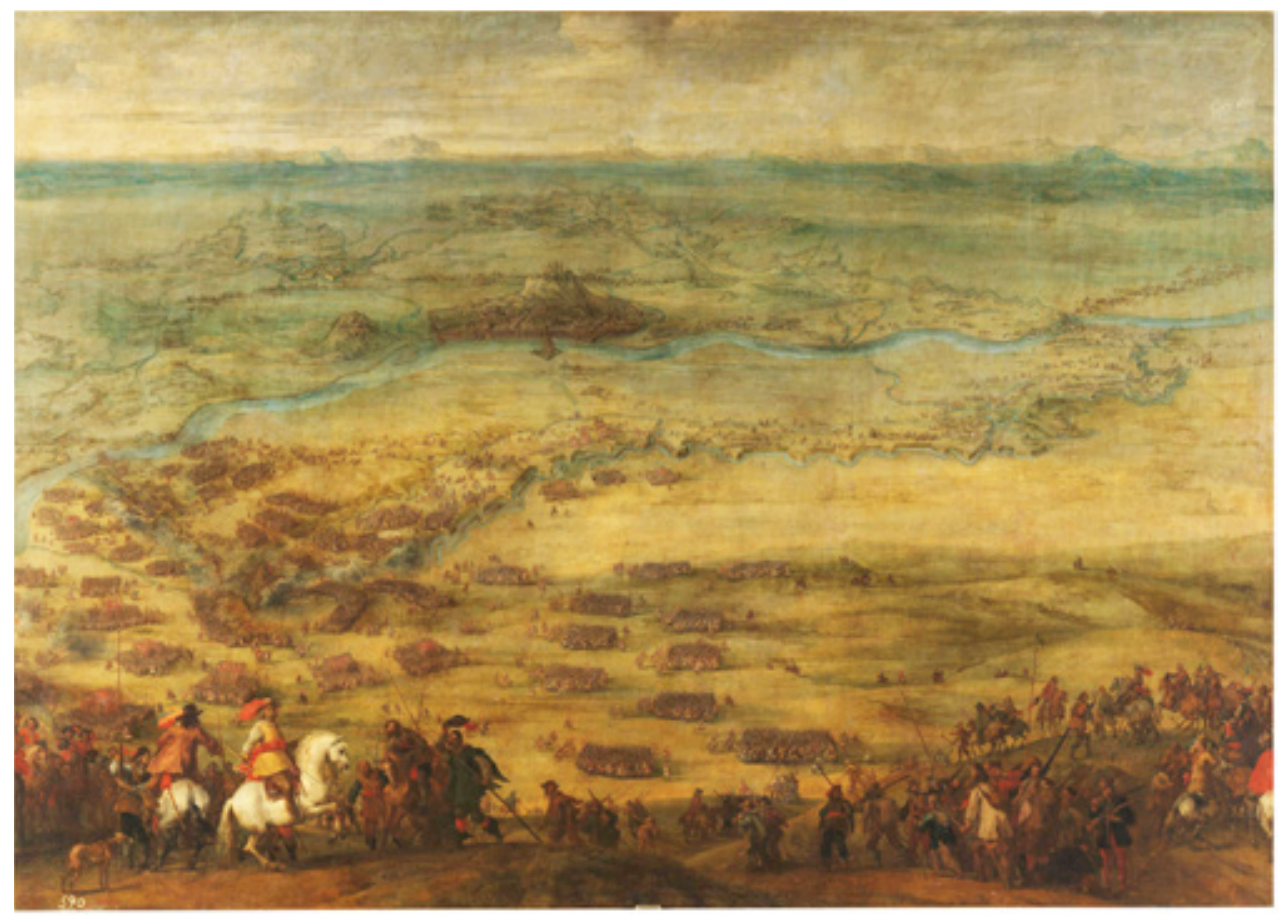

Fig.4. Socorro de Lérida. 1646. 
Poco después de su llegada, dieron inicio los trabajos de aprovisionamiento de materiales para la obra de los fuertes y a la vista de ello, el 29 de mayo, atacaron los moros con gran cantidad de tropas de caballos y peones, con el propósito de estorbar las comunicaciones de los fuertes extramuros de la plaza e impedir el acopio de materiales que se hacía en los alrededores para dicha obra "que se encargó a dicho maestre de campo" (AGI, Indiferente, 122, N.50), de estos fuertes. Esta vez salió con parte de la guarnición de la Plaza, y con el tercio del conde de Frigilana y caballería que se le había enviado de España "para dar calor a dichas fábricas" (AGI, 122, N.50), obligándoles tras más de cuatro horas de incansable pelea a retirarse, con grandes pérdidas de muertos y heridos ${ }^{6}$.

Al día siguiente, 30 de mayo, "dio principio a la fábrica del fuerte de San Pedro" (AGI, 122, N.50), que según el propio Osorio la acabó en breve tiempo, recibiendo despacho dándoles las gracias el 11 de julio. Es decir, se había levantado en apenas un mes, lo que nos da idea de lo reducido de sus dimensiones y de la calidad de la obra. Comenzó luego la construcción del fuerte de Santo Tomás, en el dicho puesto de la Cantera, que también terminó en breve tiempo, pues al parecer trabajaban incluso por la noche. Relata Osorio que habiendo venido una noche los moros con gran número de tropas a demoler lo que se estaba fabricando, los estuvo observando, mientras continuaban las obras, y cuando se arrimaron a menos de un tiro de arcabuz, mandó subir al puesto una pieza de artillería, con la que les obligó a desalojarlo, "y en pocos días terminó la obra". (AGI, 122, N.50). De aquí pasaron a reparar el fuerte de San Francisco que amenazaba ruina, "y le compuso con cuatro puntas de diamante en forma de ángulo" (AGI, 122, N.50). Por cuatro veces hicieron intentos los moros sobre este punto para impedir las obras pero fueron rechazados con pérdida considerable de su gente. Así mismo reparó las murallas y los cuarteles de Infantería, poniendo la Plaza en toda defensa ${ }^{7}$. A finales de agosto de este año 1670 le llegaba a Osorio el reconocimiento real por el socorro de avituallamientos que había llevado a la fuerza del Peñón, que se encontraba con extrema necesidad.

En agosto de 1670 el gobernador Osorio certificaba que el capitán don fuan (ilegible) de la Peña, uno de los del tercio del maestre de campo del excelentísimo señor conde (ilegible) de los Cameros "que vino de socorro a esta plaza para la reedificación de dos fuertes" en el encuentro del 29 de mayo se habia portado con valor y con su acción había contribuido a que se pudiese llevar adelante la obra. (Este documento aparecía a la venta en la web, en todocolección).

$7 \quad$ ¿Estaría incluido en estos reparos el torreón de las Beatas? 
Las últimas noticias de su estancia en Melilla son de primero de octubre de 1671, en que se le agradecían los servicios que había prestado el pasado 5 de agosto de ese año con ocasión del ataque que habían realizado los moros con numerosas fuerzas de a pie y a de a caballo, que corrieron la línea exterior que defendían los recientes fuertes, a los que resistieron y causaron numerosas bajas "matando muchos de ellos, y siete caballos" (AGI, 122, N.50). El 15 de diciembre se le daba en Melilla certificación de sus servicios ${ }^{8}$, por lo que suponemos que todavía sigue en la Plaza. Según Estrada, el 28 de agosto de 1673, Osorio participa con su Tercio en la toma de Alhucemas (1978, p.554 y 558), noticia que nos parece un tanto dudosa, pues en principio, en esas fechas no mandaba ningún Tercio, y además dada la importancia del hecho, se hubiese referido a él en alguna de las, al menos cuatro, relaciones de servicio que envió al Consejo de Indias, y este hecho no aparece reseñado en ninguna de ellas. Le sucedería en el cargo de gobernador el capitán de caballos Diego de Arce.

El 22 de febrero de 1673, según aparece en unas notas biográficas 9 , "la reina regente Mariana de Austria lo nombraba gobernador de Costa Rica, para suceder a Juan López de la Flor y Reinoso, pero no aceptó el cargo y en su lugar se designó a Juan Francisco SáenzVázquez de Quintanilla y Sendín de Sotomayor". Tal vez la pobreza de esa provincia, poco poblada y eminentemente agrícola, le hiciese esperar mejores oportunidades. En 1674 continuaba con sus pretensiones de obtener algún cargo en Indias, y era comisionado en ese mismo año por tres veces: ocupando el tercer lugar para el gobierno de Chucuyto; el segundo para el corregimiento de Ica; y el tercero para el de Paita, sin que llegase a obtener ninguno de ellos. Por fin el 14 de enero de 1675 su majestad le hacía merced de la Alcaldía Mayor de la provincia de Zapotitlán, por otro nombre San Antonio de Suchitepéquez, en Guatemala, nombramiento que esta vez si aceptaba, del que se le despachaba título en 25 de febrero.

A finales de junio embarcaba hacia Indias acompañado de tres criados: su sobrino Blas Gutiérrez de Osorio, de 18 años de edad; Agustí Parejo y Godoy, natural de Málaga, y Juan Martínez de Molina, paisano suyo, de 30, que había servido durante tres años en la guerra de Portu-

AGI. Indiferente, 125, N.159.

https://es.wikipedia.org/wiki/Francisco Osorio de Astorga. 
gal, de donde volvió hecho Alférez, y luego pasó a servir al presidio de Melilla, en el que había estado cuatro años, junto a don Francisco ${ }^{10}$. [5]

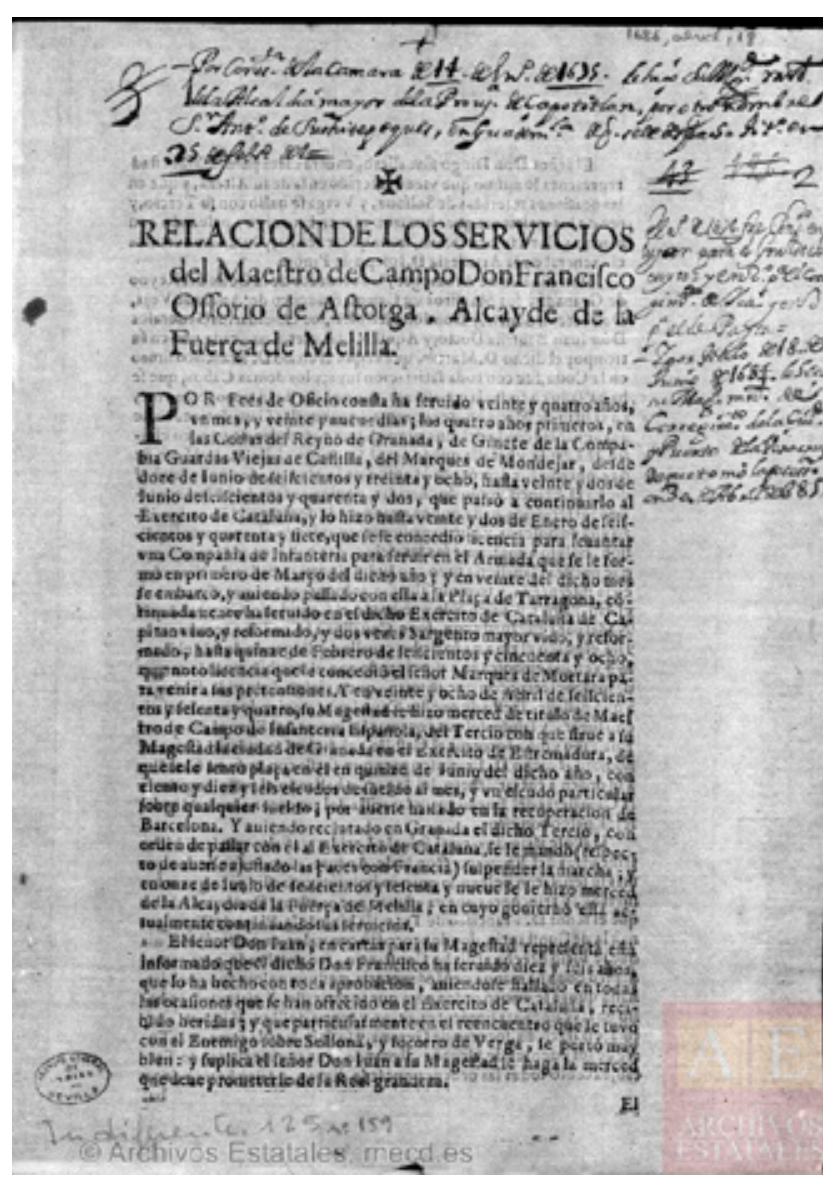

Fig. 5. Relación de Servicios de Antonio Osorio. AGI Indiferente125, N.159.

Pasado los cinco años de su mandato, y tras habérsele hecho la correspondiente residencia o auditoría de su proceder durante dicho tiempo, en la cual se le declaraba "por bueno, recto y limpio, juez celoso del servicio de ambas majestades, y cuidadoso en el buen tratamiento, conservación y aumento de los naturales, y de su enseñanza en las cosas de nuestra Santa Fee" (AGI, Indiferente, 125, N.159), se le concedió el gobierno de la provincia de Tlaxcala, en la Nueva España.

El castellano de la fuerza de San Juan de Ulúa y el alcalde mayor de la Nueva Veracruz comunicaban al virrey, conde de Paredes, que el 17 de mayo de 1683 se habían visto hasta 24 velas enemigas, las cuáles al día siguiente, aprovechando el buen tiempo habían entrado en el puerto y habían tomado la ciudad, y que dicha escuadra iba mandada por el pirata Lorenzillo ${ }^{11}$. El 21 el virrey ordenaba se hiciesen los preparativos necesarios para socorrer la ciudad, eligiendo como lugar de

10 AGI. Contratación 5440, N.2, R.161.

11 El 18 de mayo la escuadra enemiga, compuesta la mayoría por gente francesa, desembarcó casi 800 hombres, tomando la ciudad.Venía por general el francés Nicolás Briñón, y por almirante Lorencillo, holandés casado en Canarias, que habia servido en la armada de España. 
concentración de todas las fuerzas que se fuesen reuniendo el paraje de Tuxtla y Cotaxtla, a 10 leguas de la ciudad de Veracruz, "y atendiendo a la actividad, prudencia, práctica e inteligencia militar de dicho maestre de campo don Francisco Osorio de Astorga" (AGI, 125, N.159), con despacho que le daba ese mismo día, lo nombró Teniente de Capitán General, ordenándole que bajase desde la ciudad de Tlaxcala, donde se encontraba, a dicho lugar, con toda la gente de armas que tuviese en ella y con la milicia urbana, y esperase allí a toda la demás tropa y milicias que irían acudiendo para ponerse bajo su mando. Al día siguiente, llegadas noticias del asalto y saqueo de la ciudad, el virrey le ordenó, que sin dilación alguna, con la gente que hubiese llegado marchase a Veracruz y "midiese sus fuerzas con el enemigo procurando acometerle" (AGI, 125, N.159), para castigarlo e impedir que volviesen a sus embarcaciones, y que de todos los modos posibles procurase quitarles todo lo que habían saqueado. Previendo el virrey que a esta operación había de bajar mucha gente de a caballo, nombró por gobernador de la caballería al capitán de caballos corazas don Francisco Pozuelos de Espinosa, ingeniero militar de aquel reino, avisándole que habría de estar a las órdenes de dicho don Francisco ${ }^{12}$. [6]

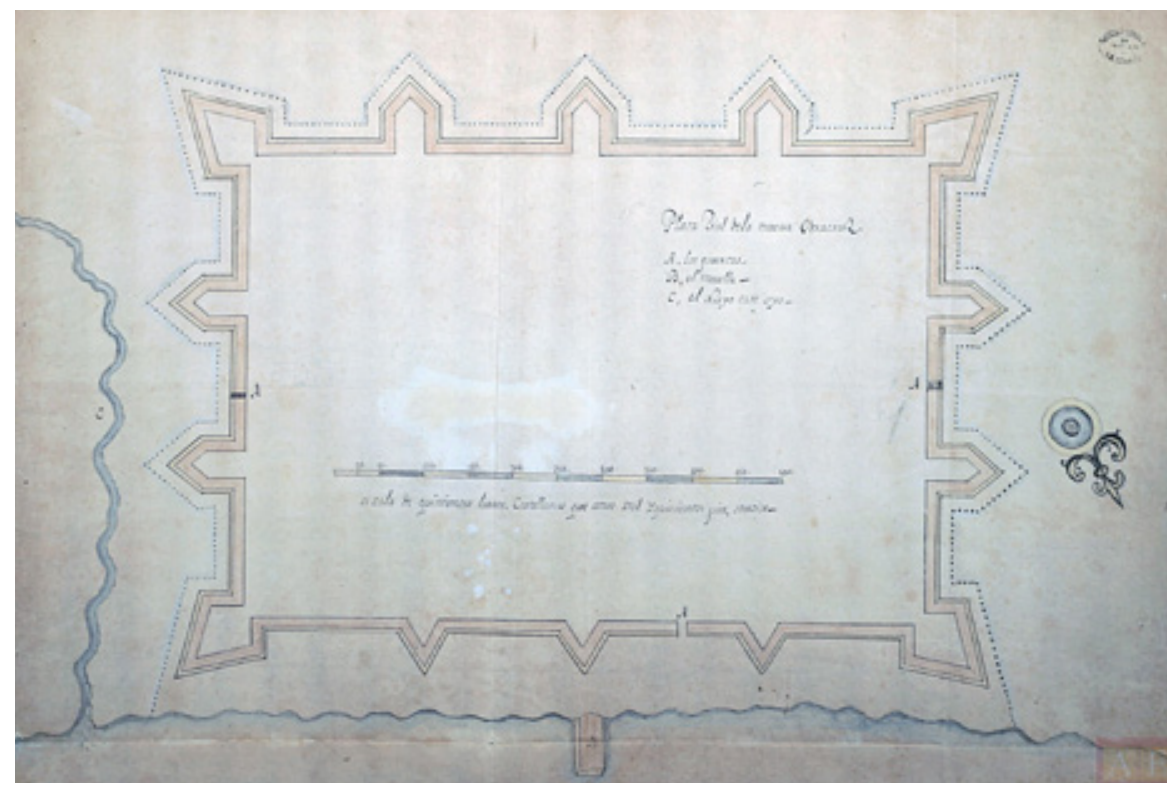

Fig. 6. Planta de la Nueva Veracruz por Francisco Pozuelo. AGI. MP, México, 75.

12 AGI. Indiferente, 125, N. 159. Este ingeniero presentaba en agosto de 1683 un proyecto para la fortificación de Veracruz. AGI. MP, México, 74 y 75. 
El 23, ante la llegada de las tropas, el enemigo abandonó la ciudad y logró embarcarse llevándose consigo un importante botín, en mercancías y rehenes, "y por haber hecho prisionero dicho enemigo pirata a don Luis Bartolomé de Córdova y Zúñiga, que era corregidor de SM de la ciudad de Veracruz, el virrey nombró el 26 de mayo de 1683 al dicho maestre de Campo, don Francisco Osorio de Astorga, por Corregidor en ínterin, de dicha ciudad de Veracruz, para que ejerciese este oficio" (AGI, 125, N.159). Ese mismo día le comunicaba por carta que procurase prender y enviar a México a un hombre que decía llamarse don Antonio de Benavides, "que se le tenía por sospechoso en el servicio de SM" (AGI, 125, N.159) 13 .

Los piratas se mantuvieron en aquellas aguas refugiados en la isla de Sacrificios, muy cerca del puerto de Veracruz, donde tenían prisioneros a los vecinos y soldados que habían podido capturar, y don Francisco con la gente de Cosamaloapan estuvo obstaculizando los desembarcos que hacían en la boca del río de Medellín en busca de agua y carne, matando a algunos de ellos y destrozándoles dos piraguas, de manera que después de esto ya no volvieron a tomar tierra. En los meses que estuvo de corregidor "asistió con todo cuidado a la limpieza de los templos que quedaron profanados y también a la de la ciudad y casas, y a dar sepultura a los cuerpos que murieron en la invasión" (AGI, 125, N.159) y así mismo desclavaron y montaron la artillería de la plaza y baluartes de las bandas Sur y Norte que los piratas habían dejado clavada, y rotos sus montajes y cureñas. En este puesto de Corregidor y Gobernador de Armas de Veracruz se mantuvo hasta el día 1 de diciembre, en que llegó a la ciudad su sucesor el sargento mayor don Pedro de Cepeda y Lira.

Encontrándose en Veracruz, con fecha 18 de junio de 1684 su majestad, en atención a sus servicios, le hacía merced del título interino de Corregidor de la ciudad de Veracruz, por tiempo de tres años, para que lo ejerciese en lugar de la persona que estaba nombrada para ello ${ }^{14}$, y sir-

13 Este curioso personaje, marqués de San Vicente, habia desembarcado en Veracruz el 22 de mayo, casi al mismo tiempo que los piratas, diciendo serVisitador general de la Nueva España enviado por la reina Mariana de Austria. Acusado de connivencia con los piratas, fue arrestado y llevado a la ciudad de México, donde fue incapaz de mostrar sus credenciales, siendo finalmente ejecutado.

14 A Cepeda se la habia nombrado Corregidor el 24 de febrero de 1682, embarcando para Indias el 4 de marzo de 1683, pero por un error se habia nombrado también para dicho cargo a don Francisco Osorio. Se mantuvo a éste último y se le devolvieron a Cepeda, con intereses del 8\%, los 3.500 pesos de donativo que habia pagado por el nombramiento. AGI. Indiferente 125, N. 76. 
viendo dicho cargo falleció en esa ciudad el año de 1686 "a ocho días de haber desembarcado en el castillo de San Juan de Ulúa el nuevo virrey, conde de la Monclova, cuyos servicios, experiencias militares y buenas prendas le tuvieron en el concepto del conde de Paredes, su antecesor, por el único entre los militares que había entonces en su reino para este empleo" (AGI, México, R.1,N.28).

\section{Diego de Arce}

Tras cesar en el mando de la plaza el gobernador Francisco Osorio, le sucedía, como vimos el capitán de caballos don Diego de Arce.

Había empezado a servir en la Armada, en una compañía de Piqueros, en el año 1636, obteniendo por real cedula el sueldo de 12 escudos como alférez reformado. Pasó a Melilla donde sirvió de capitán de infantería y de caballos, siendo nombrado el 8 de noviembre de 1655 gobernador interino, por ausencia de su propietario, cesando en el cargo el 29 de agosto de 1656. Pasó luego a gobernar en propiedad la plaza del Peñón, "en cuyo tiempo manifestó su gran celo y valor al real servicio en todas las ocasiones que se ofreció de sitios y operaciones, apresando moros, ganado y caballos, con que aumentó dicha compañía, trigo, y cebada, en tiempo en que padecía la plaza extrema necesidad" (AGI, Indiferente, 135, N.200). En uno de los encuentros que tuvo en estas salidas, quedó con varias heridas, siendo apresado y llevado como cautivo, "cuyo rescate le costó un caudal de 1.800 reales de a ocho" (AGI, 135, N.200). Casado tal vez en Melilla, sabemos que una de sus hijas contrajo matrimonio en esta plaza con el alférez Pedro Moreo.

Al parecer, se le nombraba gobernador de la plaza de Melilla en agosto de 1672, desempeñando el cargo hasta el 3 de octubre de 1674 , en que murió de enfermedad ${ }^{15}$ y no como consecuencia de un ataque a la plaza como leemos ${ }^{16}$, siendo enterrado en la Capilla Mayor, sepultura de los alcaides Morales, 1995, p. 66). Ese día se nombraba gobernador interino a su yerno el capitán de infantería y de caballos don Pedro Moreo, que ya lo había sido anteriormente, con ocasión de haber pasado don Diego a la Península a recobrarse.

AGI. Indiferente, 135, N.200.

16 La fecha de agosto de 1672, y la de su muerte en defensa de la Plaza la tomamos del blog de Fuan F. Aranda brevecronologiademelilla.blogspot.com/.../siglos-xvï-y-xviii-agosto1603-marzo 1799. 


\section{Pedro Moreo}

Había nacido en Melilla, hijo de don Lázaro Moreo, alférez de la compañía de caballos de guarnición en la plaza, natural también de ella, y nieto de Francisco Moreo, que había empezado a servir en 1570 de soldado de picas y más tarde de arcabucero y hombre de campo, el cual había fallecido en Melilla, de enfermedad, el 25 de diciembre de 1608. [7]

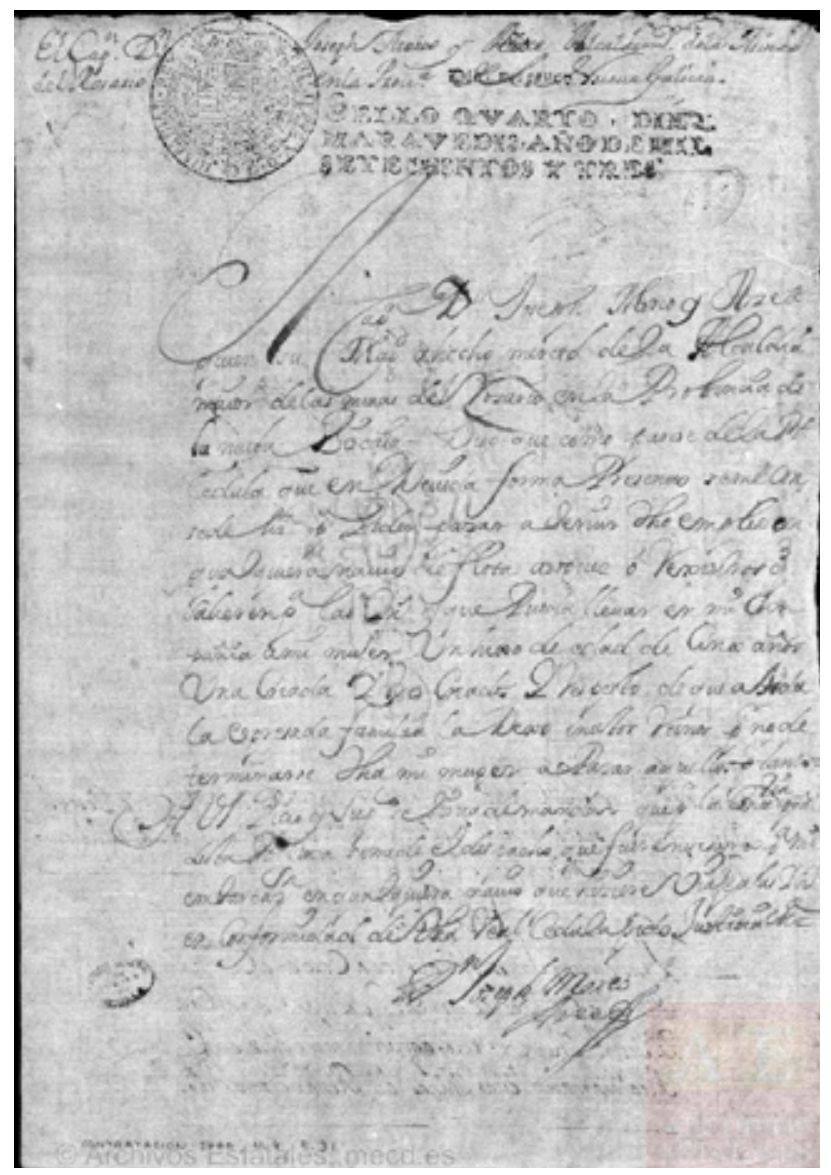

Fig. 7. Firma de fosé Moreo Arce. AGI Contratación 5460, N.4, R.31.
$\mathrm{Su}$ tío Pedro Moreo, empezó también a servir en una de las compañías de guarnición en la plaza, hacia 1608, de soldado de picas, y durante sus más de 30 años de servicio fue hombre de campo, adalid, alférez de caballos y capitán de la compañía de caballos jinetes de la plaza. Estando mandando esta compañía, en marzo de 1632, al haber fallecido el gobernador don Luis de Sotomayor, padre del homónimo anterior, se le nombraba gobernador interino, cargo que desempeñó hasta la llegada al año siguiente del nuevo alcaide Tomás Messía. Y habiendo pasado éste a Málaga en febrero de 1635, estuvo por segunda vez gobernándola interino hasta 1636 , en que se nombró a don Pedro de Palacios y Guevara. Fallecía de enfermedad el 12 de octubre de 1638 .

Lázaro Moreo, su padre, sirvió durante más de cincuenta años en la caballería de la plaza, primero como soldado arcabucero, "y por haberle herido los moros en un brazo, mandó SM que el sueldo que 
tenía en la caballería lo gozase en la infantería, donde se le sentó" (AGI, Indiferente, 135, N.200). Fue promovido a alférez de dicha compañía de caballos, y sirviendo este empleo, al haber matado los moros al maestre de campo don Luis de Sotomayor, alcaide de ella, lo nombraron gobernador interino de la plaza el 18 de julio de 1649, sustituyendo a don Andrés del Carte que lo había sido desde el 6 de mayo, día en que mataron al gobernador. Tuvo el cargo hasta el 29 de octubre de dicho año, en que en virtud de orden de su majestad, entregó la plaza al maestre de campo Jordana Xerez, “y después quedó jubilado con 12 escudos de sueldo al mes que su majestad fue servido concederle" (AGI, 135, N.200)

Pedro tomó asiento como soldado aventajado de infantería el 7 de julio de 1658, sirviendo durante más de 37 años, en los empleos de alférez vivo y reformado y capitán de infantería y de caballos. Cuando Diego de Arce estaba para pasar a España a curarse, recibió despacho de su majestad para que dejase el gobierno de la plaza al capitán Pedro Moreo, que se encontraba entonces gobernando la plaza del Peñón.

Gobernando esta última plaza, se le aprobaba y daban las gracias por haber salido a tomar dos piezas de hierro de artillería que tenían los moros y haberlas metido en la plaza, y por las buenas disposiciones y prevenciones que había hecho al encontrase a la vista gran número de moros que venían a sitiarla. Constaba así mismo por certificación, que encontrándose en Málaga con el bergantín del Peñón, y llegada noticia de la extrema necesidad que padecía Melilla, se le ordenó que una vez cargado el bergantín con bastimentos, junto con una fragata, los llevase a dicha Plaza. Durante el viaje cayó sobre ellos un navío enemigo, que les hizo buscar refugio en el Peñón, del que, ante la urgencia, salió con tiempo contrario ayudado con los remos, y estando la fragata a tres leguas de Melilla, varó sobre una laja, y se le abrió una vía de agua que la anegaba, "y se hubiese perdido si no llega a ser por su ayuda, que con el celo que acostumbraba en el real servicio logró sacar las provisiones y salvar la vida de la gente, aliviando a la plaza con el socorro que en ella introdujo" (AGI, 135, N.200) [8]

En el sorpresivo ataque que dieron los moros el 11 de octubre de 1686, gracias a su buena disposición se pudo retirar nuestra gente sin más pérdida que la de dos muertos y tres heridos, uno de los cuales fue su hijo el tirador don José Moreo y Arce, que recibió dos balazos, en boca y mano, causando al enemigo gran daño, que pasaron de cincuenta los muertos y de ciento los heridos. Por esta acción le concedió su majestad a José el grado de capitán de infantería. 


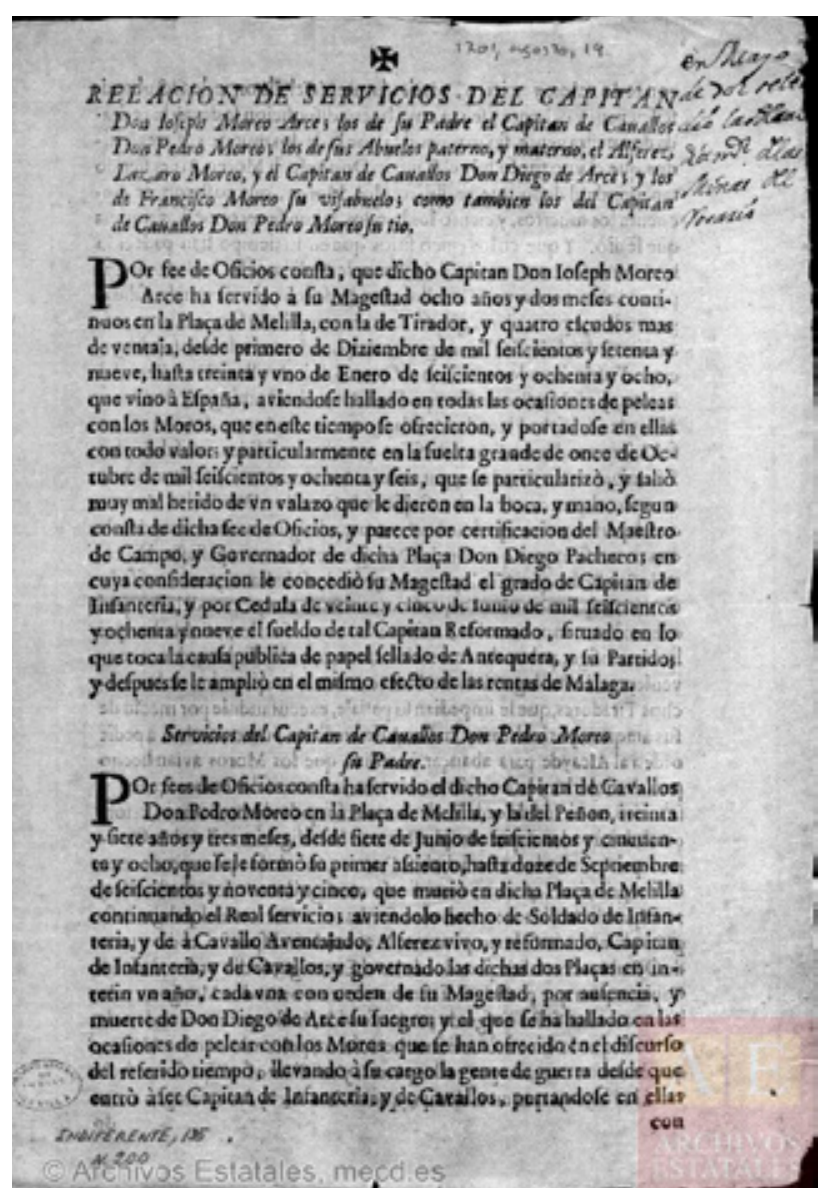

Fig.8. Relación de Servicios de los Moreo. AGI Indiferente 135, N. 200.
Encontrándose el fuerte de San Pedro en apuros, $\mathrm{y}$ habiendo avisado el alférez que lo mandaba que los moros tenían ya muy cerca la mina, se le ordenó que con dos mangas de infantería fuese a socorrerlo, por ser el que más apretado se hallaba, lo que logró llevar a cabo a pesar de tener que atravesar sus ataques $y$ trincheras ocupadas por muchos tiradores. Estando en el fuerte envió a pedir orden al alcaide para poder contraminar la que hacían los moros, pero no se la dieron y le mandaron retirarse, lo que hizo dejando reforzado el puesto y exhortando a sus defensores que cumpliesen con su obligación.

Ante la apurada situación en que se encuentran los fuertes exteriores, que según relata Moreo, habían padecido en esos años hasta cinco sitios, llega de refuerzo a Melilla el tercio del maestre de campo don Antonio Domínguez de Dura, el cual, junto con el general de la artillería don Bernabé Ramos alcaides de dicha plaza de Melilla, certificaban que el capitán de infantería y de caballos don Pedro Moreo se había hallado en las salidas generales y particulares que se hicieron durante el asedio de los fuertes extramuros de la plaza para socorrerlos y desalojar a los enemigos. El 5 de noviembre, ante el acoso de los moros 
repetía la salida con dos mangas para reforzar dicho fuerte de San Pedro, peleando con los moros que lo tenían cercado por todas partes, estando a riesgo de perder la vida. En esta salida perdía la vida el alcaide don Francisco López Moreno. Ese mismo día, como veremos, se perdía también el fuerte de Santo Tomás o de la Cantera.

Fallecía en Melilla el día 12 de septiembre de 1695, dejando al menos dos hijos, uno de ellos el mencionado José, a quien en junio de 1689 se le concedía el sueldo de capitán reformado "situado en lo que toca la causa pública de papel sellado de Antequera y su partido, y después se le amplió en el mismo efecto de las rentas de Málaga" (AGI, 135, N.200). En enero de 1703 nombraban a José gobernador de las minas del Rosario ${ }^{17}$, en la provincia de la Nueva Vizcaya, embarcando en abril en el navío Nuestra Señora de Regla, dejando en España a su mujer, que no había querido hacer el viaje, y a un hijo de cinco años ${ }^{18}$. De otro hijo de Pedro llamado Ángel, sabemos que en 1703 se le daba despacho de su nombramiento de teniente (Cárdenas, 2005, p.422).

\section{José de Frías}

Tras la muerte de Diego de Arce, el 1 de mayo de 1675 se nombraba gobernador al sargento mayor don José de Frías. Era hijo de don Juan Francisco de Frías, que había servido a su majestad más de 30 años, "en diferentes ocupaciones de papeles" (AGI. Indiferente, 123, N.47), Durante el levantamiento de Portugal fue cogido prisionero y estuvo encerrado cuatro años, quitándole una considerable hacienda. Falleció siendo Veedor del contrabando de ciertos lugares del partido de Sevilla.

Don José había empezado a servir de soldado en mayo de 1652 en el ejército de Extremadura, obteniendo de don Luis Méndez de Haro patente de capitán de una de las compañías del Tercio de dicho ejército, el 27 de septiembre de 1658, sirviendo de capitán hasta agosto de 1664 en que pasó a reformado, permaneciendo en esta situación hasta noviembre de 1666 en que fue nombrado por el marqués de Caracena, jefe del ejército de Extremadura, sargento mayor de la plaza de Olivenza, permaneciendo en este puesto hasta el 24 de abril de 1668 en que, con motivo de haberse firmado la Paz con Portugal, se hizo entrega de esta plaza a los portugueses (AGI, Indiferente, 123, N.47). 
Estando sirviendo en el Regimiento de la Guardia de su majestad, en la compañía del marqués de las Navas, en atención a sus servicios, se le hacía merced de la Alcaldía de Melilla con despacho de 1 de mayo de 1675. Llega a Melilla en un momento de relativa tranquilidad, manteniéndose en este tiempo "buena correspondencia con los moros, hasta el año de 1677 en que el rey Muley Ismael, desembarazado de su sobrino que se había hecho fuerte en Marruecos, mandó a su alcaide, romper la tregua de muchos años que se tenía con la plaza" (Estrada, 1798, p.553).

La Gaceta de Madrid de agosto de 1677 publicaba, como vimos, noticias sobre Melilla correspondientes a los primeros días del mes anterior y decía que el rey Muley Ismael, había vencido a su sobrino Muley Ahmed, y recuperado la ciudad de Marruecos después de tres años de sitio, y que su hijo primogénito, gobernador de Fez, había salido hacia Levante con un ejército de 3.000 caballos, lanceros y tiradores, sin que se supiese su destino, "pero nuestro vigilante gobernador don Josep de Frías" (Gaceta, 1677a, 17 agosto, p.31), estaba haciendo todo lo posible para enterarse por medio de confidentes moros.

El gobernador Frías, al que se le había concedido el grado de maestre de campo el 29 de octubre de 1676 (AGI, Indiferente 126, N.63), informaba ese año 1677 del mal estado en que se encontraban los cuarteles de infantería y caballería, y la mala localización de $\operatorname{ellos}^{19}$. Señalaba que el primer recinto estaba formado por buenas murallas, aunque se encontraban algo deterioradas (Bravo Nieto y Fernández Uriel, 2006).

La noche del 10 de julio de 1677, los centinelas de uno de los reductos cercanos al río, el de San Lorenzo (Estrada, 1798, p. 553) ${ }^{20}$, a la otra parte del mismo, oyeron gran ruido de armas y movimiento de tropas, por lo que se pusieron en guardia y dieron aviso a la Plaza. A la mañana siguiente, en la descubierta que acostumbraba hacer la caballería, fueron acometidos por todas partes con tropas de a pie y acaballo, aguantando firme el choque, mientras acudían refuerzos al amparo de la artillería y mosquetería de la Plaza. Duró el combate todo el día, hasta la caída del sol, en que con grandes pérdidas se retiraron de su intento, sin habernos causa baja alguna ${ }^{21}$. [9]

\footnotetext{
19 Carta a su majestad de 29 de noviembre 1677. (Rodríguez Puget, 1995, p. 111).

20 Estrada, que tiene a la vista la Gaceta cuando redacta su Población, es el que añade el dato de que se trataba del fuerte de San Lorenzo. .

21 GACETA (1677b), p.47v.
} 
Arrecian los moros sus ataques a los fuertes exteriores, teniéndose encuentros con ellos durante todo el mes de enero del siguiente año 1678, soportando señalados ataques los días 18 y 23. En la descubierta del Campo que hacía la caballería en la mañana de dicho día 23, al acercarse al fuerte de Santo Tomás, de la Cantera, los moros, que andaban emboscados en la vaguada que discurría frente al mismo, les salieron al paso con ingente cantidad de infantería y caballería, haciéndoles frente protegidos por la albarrada de piedra que protegía al fuerte. Tras más de

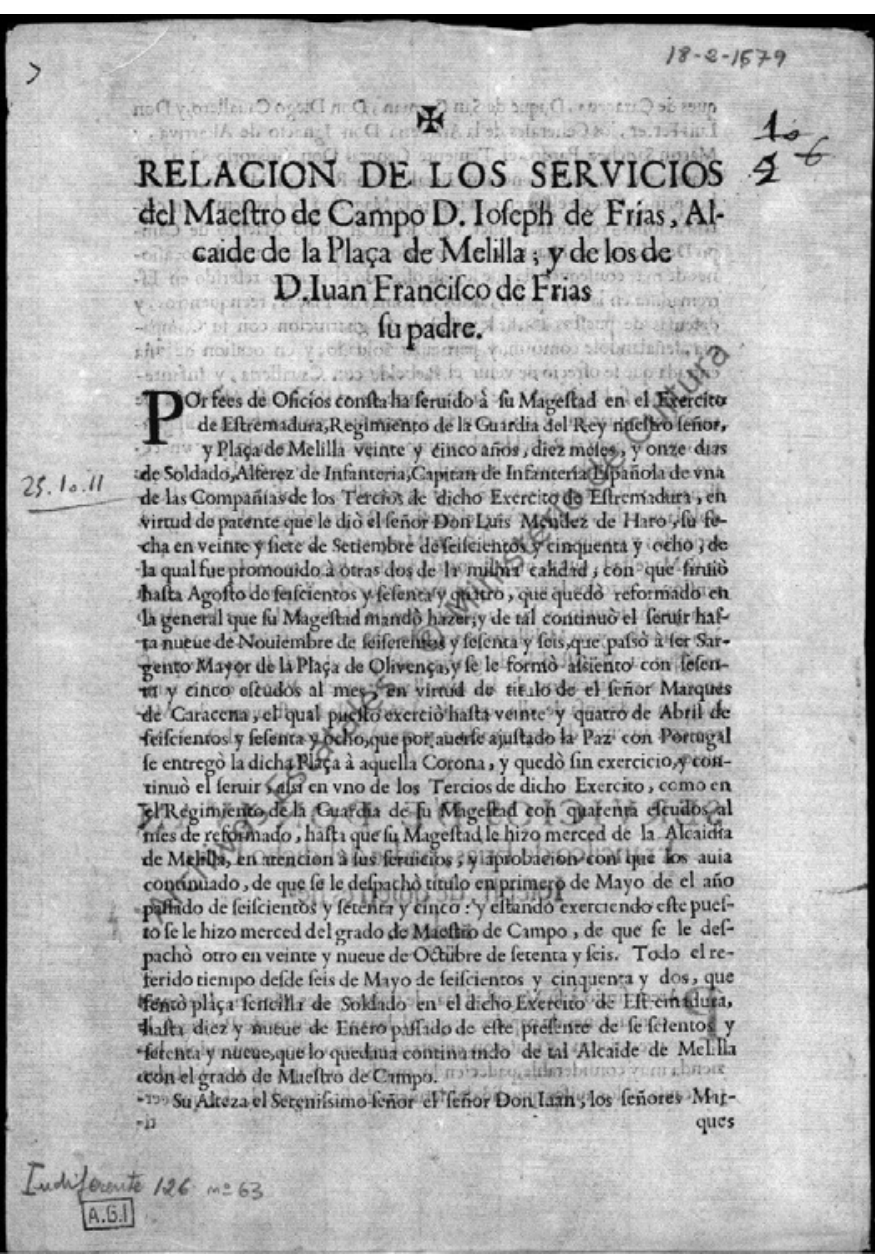

Fig.9. Relación de Servicios de fosé de Frías. AGI Indiferente 126, N.63.

dos horas de soportar la cadencia de fuego que se les hacía, se retiraron ante el estrago que les ocasionaba. "Su intento era sin duda cebarnos a otras celadas y cortarnos, pero nunca han podido lograr nada de esto, por la buena orden con que se pelea y lo dirige todo nuestro gobernador don Joseph de Frías"22.

El 27 de agosto de 1678 se presentaba ante el fuerte de San Lorenzo un gran ejército de cerca de 6.000 moros, y asistidos de ingenieros ex-

22 GACETA (1678a), p.52. 
tranjeros, habían comenzado a excavar una mina a poca distancia, pero don José de Frías, había enviado a 19 hombres al fuerte con las herramientas necesarias para contrarrestarla, cavando otra a cuatro pasos de aquella. Los moros, visto el daño que les podía hacer esta medida, intentaron cortar la comunicación del fuerte con la Plaza, pero a pesar de ello se les había podido socorrer de municiones, víveres y artificios de fuego para muchos días. El día 1 de septiembre, a las ocho de la mañana, dieron los moros un fuerte ataque con gran número de infantería asistida de caballería, pero fueron rechazados bizarramente, causándoles más de 80 muertos, a los que había que sumar otros 400 como resultado del fuego de artillería y mosquetería que se les hizo desde la plaza. Ante la apurada situación que se encontraba el fuerte, desde Málaga aprestaron rápidamente refuerzos, que llegaban a Melilla el día 8 con el capitán Francisco Moreno que traía gente, bastimentos y municiones, pero ya se habían retirado los moros, que habían logrado tomar el fuerte hacía tan solo cuatro días (Morales, 1995, p. 69) ${ }^{23}$. Las malas condiciones de defensa de estos fuertes hicieron pensar en la necesidad de disponer de otro tipo de fortificación en esos puntos, para asegurar con ellos la defensa de la Plaza. En esta idea estaba trabajando el gobernador, al "que asiste el oportuno requisito de famoso ingeniero" ${ }^{24}$, el cual enviaba a la Corte información sobre todo ello a través del capitán Moreno. La Gaceta informaba que el 21 de octubre los moros intentaban canjear por otros de su nación, a los cautivos que tenían en su poder procedentes de la guarnición del fuerte de San Lorenzo Según informaba un moro que había venido a la plaza para tratar de intercambiar prisioneros, en este ataque había muerto un pariente del rey que mandaba su ejército, el cual tenía el designio de tomar todos los fuertes exteriores y poner sitio a la Plaza, "alentándole mucho a ello un ingeniero francés que le asistía, que también murió en la misma ocasión" ${ }^{25}$.

El enemigo, prosiguiendo en su empeño de ir eliminando las defensas exteriores que protegían la Plaza con el fin de aproximarse a ella, el 25 de febrero de 1679 se presentaba ante el pequeño fuerte de San Francisco con un formidable ejército de 8.000 turcos, entre los que venían 1.400 de caballería, dejándolo completamente cercado. Intentaron tomarlo al asalto, pero escarmentados ante el fuego que se les

Estrada da como fecha de la toma de San Lorenzo finales de octubre, seguramente guiado por la noticia del 21 de ese mes que recogía la Gaceta.

GACETA, 1678b, p.219V-220.

GACETA, 1678c, p.232-232v. 
hacía, cavaron una mina a unos veinticinco metros del fuerte, que avanzaron rápidamente ayudados por la poca calidad del terreno, y cuando ya se encontraban cerca de los muros, debajo del terraplén que los protegía, fueron oídos por los del fuerte, que excavaron una contramina en su busca, y al dar con ellos "a granadazos y pistoletazos los retiraron algunos pasos hacia la boca exterior de la obra" (AGI, Indiferente, 126, N.63). Los 17 soldados que defendían el fuerte, después de quince días de asedio, sin poder atender a la vez a su defensa asistiendo al parapeto y al minado que les hacían, comunicaron el día 12 a don José, la difícil situación en la que se encontraban. Tras reunir en consejo a los oficiales, el gobernador les enviaba aviso de que procurasen retirarse amparados en la noche, y que volasen el fuerte. Lograron salvarse todos menos seis de ellos, de los que cinco quedaron tendidos en el campo y otro sepultado entre sus ruinas (Morales, 1995, p. 70) ${ }^{26}$. A la mañana siguiente, resuelto don José salir a por los cadáveres para darles cristiana sepultura, y ante la esperada oposición de los moros, dispuso una columna de escogidos tiradores, que apostados en los sitios convenientes causaron muchas bajas entre ellos, logrando recuperar los cadáveres ${ }^{27}$. Después se supo, que nada más abandonar el fuerte los nuestros, se precipitaron sobre él más de un centenar de moros en busca de los despojos, cogiéndoles de lleno la explosión, que mató a la mayoría de ellos, y dejó el fuerte completamente $\operatorname{arrasado}^{28}$. En el ataque, se estimaba que habían perdido los moros cerca de 600 hombres, bajas causadas por los bravos defensores y por el apoyo prestado por la artillería de la plaza, y por la mosquetería desde las defensas de la Albarrada.

A últimas horas de la tarde del día 22 de febrero, cercaron el fuerte de Santiago, y lograron arrimar una escala al muro, intentado repetidas veces su salto, pero al cabo del rato, ante las cuantiosas bajas que sufrían, debidas sobre todo a la cantidad de granadas y otros fuegos de artificio, que les arrojaron sus defensores, "cuya fábrica entiende admirablemente don Josep de Frías” (Gaceta, 1679a, p.90), desistieron de su intento. En

\footnotetext{
GACETA, 1679a, p.90.

GACETA 1679a, p. 89v-90v. Hacia relación la Gaceta del perro enseñado en ir y venir todos los días al fuerte, mediante el cual lograron en esta ocasión comunicarse entre ellos. Decía de los sitiadores que desoyeron las repetidas veces que intentaron que entregasen el fuerte prometiéndoles dejarles libres y amenazándoles con quemarlos con la mina que intentaban," a lo que la respuesta fue arrojar a los agresores un mazo de cuerda diciéndoles lo hacian por si acaso les faltaba para pegar fuego a la misma mina".

28 GACETA 1679b, p.125v.
} 
estos días llegaron a la plaza 50 hombres de refuerzo procedente del Peñón de Vélez, así como alimentos y municiones procedentes de la Península y de Alhucemas.

Los avisos e informes enviados a la Corte por el gobernador, referentes a la necesidad de mejorar las defensas de la Plaza, parece que tuvieron su efecto, y se esperaba por ello la arribada a Melilla del "famoso ingeniero, el teniente de maestro de campo general don Octavio Meni" (Gaceta, 1679a, p.90v), que traía las disposiciones necesarias para trabajar en las nuevas fortificaciones.

Trascurrido todo el mes de marzo y parte del siguiente con cierta calma, el 28 de abril hicieron un asomo, pero los mantuvo alejados la artillería de la plaza. El gobernador, con el fin de reforzar su defensa, hizo levantar un reducto al pie del fuerte de Santiago con capacidad para 24 hombres, intentando con ello asegurar la comunicación con la plaza, en espera de nuevos ataques.

Con los conocimientos de Meni, esperaban lograr en poco tiempo mejorar las fortificaciones de la Plaza, y restaurar las atalayas de San Lorenzo, San Francisco y Santiago, las cuales habían padecido el ataque de los moros, las dos primeras de ellas el pasado año, y la de Santiago lo estaba sufriendo desde finales de agosto hasta el 14 de septiembre de este año 1679, "y que por su heroica resistencia merecían el nombre de fuertes" (Gaceta, 1679c, p.304), no siendo esta última atalaya, al igual que las otras dos, más "que una mala torre de piedra y barro sin flancos, ni estrada cubierta, y solo servían para descubrir tierra en el Campo" (Gaceta, 1679c, p.304), A pesar de que la Gaceta no indica nada sobre ello, según Estrada, en el ataque de ese día 14 se perdió el fuerte de Santiago y los 24 hombres que lo guardaban (Estrada,1798, p554). Perdidos estos tres fuertes, Meni acomete las obras de refuerzo de las murallas, rehaciendo el tramo del Torreón de la Cal, y el fuerte de Santo Tomás, iniciando los trabajos de excavación del foso de la Alafia.

En la relación impresa de los méritos y servicios de Frías, fechada en febrero de 1679, tan solo se señala en referencia a su estancia en Melilla, que procedía con gran satisfacción y merecía que su majestad le diese gracias "así por el cuidado que ha puesto en la reedificación de las murallas de aquella Plaza, como también en la defensa de ella cuando el año pasado estuvieron los moros con intento de expugnarla" (AGI, 126, N.63). 


\section{Diego Toscano de Brito}

Apenas tenemos noticias de este gobernador. Estrada nos dice que le dieron el gobierno por los años de 1675 hasta 1682 (1798, p554), y por las fechas anotadas en la relación de Frias deducimos que debió ser nombrado gobernador en los últimos meses de 1679, o en los primeros del siguiente año 1680, permaneciendo en este cargo al menos hasta mediados del mes de diciembre de 1682 .

En la entrada que se hizo al campo el 13 de diciembre de 1680, al sitio que llaman el Arrecife se apresaron diferentes moros, "tocando de joya" uno de ellos, que era un joven de 14 años, espigado de cuerpo, trigueño, de ojos negros, natural de Farjana, al maestre de campo don Diego Toscano de Brito, gobernador de la Plaza. En la subasta que más tarde se celebró, de los moros que se habían apresado en dicha entrada, como era costumbre, se remató uno de ellos, de unos 13 años de edad, alto y recio, de pelo rubio y ojos pardos, en el soldado don Francisco de Valseca, que por el mismo precio se lo cedió al gobernador ${ }^{29}$.

Unas semanas antes de cesar en el gobierno de la Plaza, el 8 de diciembre de 1682, tras 25 años del comienzo de las obras, que se habían iniciado en tiempos del gobernador Luis Velázquez y Angulo, finalizaba la construcción de la iglesia de la Concepción (Morales,1995, p.76), en la cual Toscano había mandado edificar la capilla mayor y la capilla bajo advocación de Todos los Santos y de la Inmaculada (Bravo Nieto, $2009)^{30}$.

\section{Diego Pacheco de Arce}

A Toscano de Brito le sucedió en el gobierno de la Plaza el maestre de campo don Diego Pacheco de Arce, que había sido nombrado para este cargo el 31 de diciembre de 1682, que entonces se encontraba mandando la fuerza de Larache.

Militar experimentado, con 43 años de servicio, que había iniciado en 5 de marzo de 1642 en los estados de Flandes, donde había sentado plaza en dicha fecha, con el sueldo de 4 escudos al mes de ventaja

Genealogía. Bueno-Martinez. Los Melilla genbueno. hispagen.en.

En una de las placas, de las dos existentes, dice que don Diego "mandó reedificar la iglesia y hacer la capilla mayor" Nosotros, por los datos que se tienen, entendemos que "terminó la iglesia y reedificó la capilla mayor", capilla que ya estaba en uso en 1674, cuando se enterraba en ella al gobernador Diego de Arce. 
particulares, en la compañía del maestre de campo conde de Garciez, continuando en aquellos Estados hasta febrero de 1652 en que pasó a España con licencia del archiduque, regresando a Flandes a finales de diciembre del siguiente año, como alférez en la compañía del capitán don Manuel de Benavides, en el Tercio del maestre de campo don Francisco de Meneses. En febrero de 1655 retornaba a España con la compañía de don Francisco Zuazo, para servir en el ejército de Cataluña, pasando al de Extremadura en 1657 con el teniente general don Juan Pacheco. En estos años de guerra con Portugal ascendía a capitán participando con su compañía, a primeros de julio de 1662, en la ocupación y fortificación de la plaza de Escallón ${ }^{31}$. En 1663, estando preparándose un asalto por sorpresa a la plaza de Almeida, fue enviado por el duque de Osuna, para que con sus armas y caballo, se internase en Portugal "a realizar un particular servicio de su majestad",

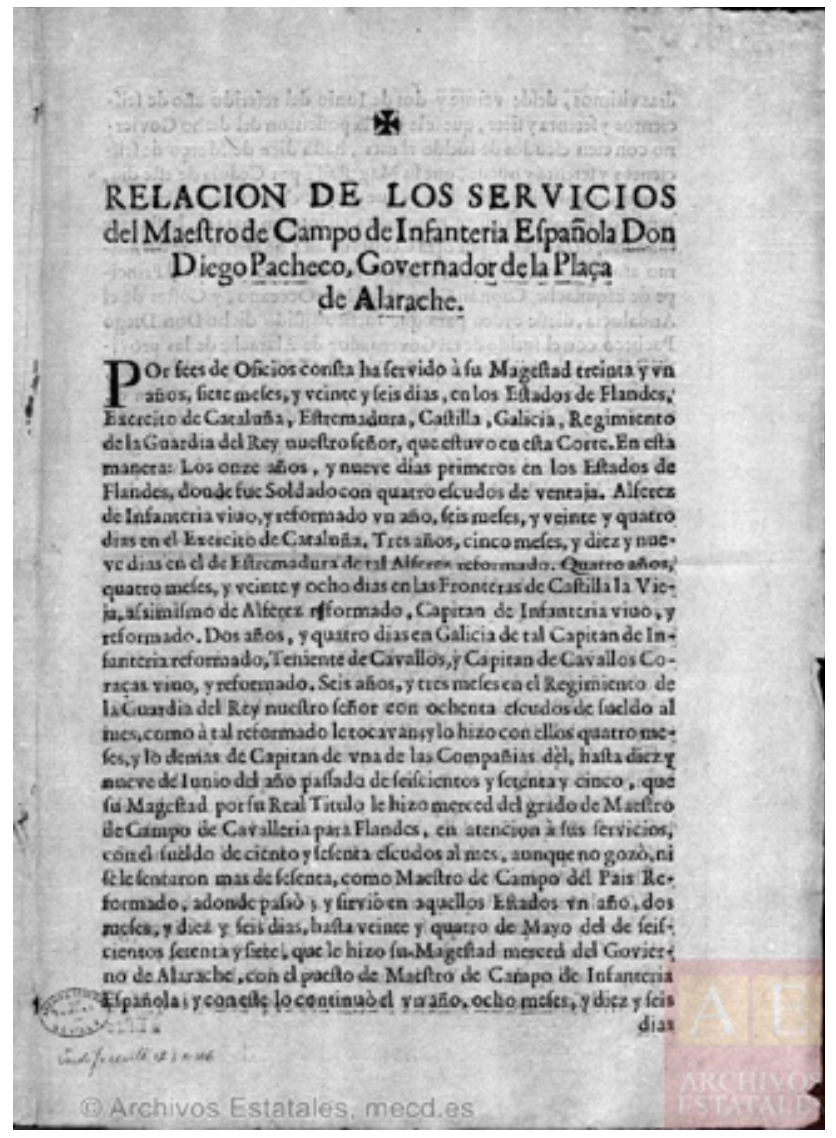

Fig. 10. Relación de Servicios de Diego Pacheco. AGI Indiferente 121, N. 166. siendo hecho prisionero y llevado a Lisboa donde permaneció preso unos meses, logrando escapar "por Olanda" desde donde regresó a Ciudad Rodrigo, obteniendo la merced de una compañía de infantería, hallándose en el encuentro que se tuvo con los portugueses ante el recién construido fuerte de la Concepción. En junio de 1664 se encontró en la batalla de Castel Rodrigo, donde era derrotado el duque de Osuna, derrota que tendría como consecuencia la demolición del recién levantado fuerte, en cuyos trabajos participó con su compañía, con la cual pasaría al socorro de Galicia, donde permaneció dos años de guarnición. [10] 
Pasaría más tarde como teniente de caballos corazas a la compañía del marqués de Belmonte, y con motivo de haber pasado dicho marqués a Flandes, el 6 de julio de 1668 se le nombraba capitán de dicha compañía. Sirvió durante más de seis años de capitán de una de las compañías de la Guardia Real, hasta que su majestad, en atención a sus servicios, por título dado el 19 de junio de 1675, le hacía merced del grado de maestre de campo de caballería para Flandes, "con el sueldo de 160 escudos al mes, aunque no gozó ni se le asentaron más de 60 como maestre de campo del País" al cual pasó, estando sirviendo en aquellos estados hasta el 22 de junio de 1677 en el que se le hacía merced del gobierno de la plaza de Larache, con el cargo de maestre de campo de infantería. Estando en esta plaza, el 19 de marzo de 1679, su majestad, le mandaba pasar a Gibraltar y que dejase el gobierno a don Lorenzo Ripalda, al que nombraba interino para el mismo.

No sabemos la causa de su envió a Gibraltar, pero en una de las relaciones de sus méritos y servicios, se dice que por cedula de 10 de diciembre de ese año 1679, su majestad ordenaba al príncipe de Esquilache, capitán general del mar océano y costas de Andalucía, que diese las oportunas órdenes para que don Diego fuese asistido con el sueldo que le correspondía como tal gobernador de Larache, "mientras se veían los Autos de la pesquisa que se hacía contra él. Y por otra cedula de SM de 20 de febrero de 1682, parece que habiéndose seguido pleito entre el señor fiscal del Consejo de Guerra de la una parte, y de la otra el dicho maestre de campo don Diego Pacheco, sobre los cargos que se le impusieron, se pronunció sentencia definitiva en 24 de octubre de 1681 y se le absolvió de ellos, mandándole restituir el gobierno de Alarache en la misma forma y manera que antes le tuvo, cuya propiedad conserva hoy día de la fecha de esta relación" (AGI, Indiferente, 121, N.166).

Como vimos, a fin de diciembre de este año 1682 se le concedía el gobierno de la plaza de Melilla. De su paso por ella no tenemos ningún dato, tan solo una cita de pasada que leemos en la relación de servicios de su deudo, el ya citado capitán José Moreo Arce. Decía éste que él había servido algo más de ocho años en la plaza de Melilla, desde diciembre de 1679 hasta enero de 1686, habiéndose hallado en todas las ocasiones y peleas con los moros que en ese tiempo se ofrecieron, portándose en ellas con todo valor, "y especialmente en la suelta grande de 11 de octubre de

31 Fernández de Buendía (1662). 
1686, que se particularizó, y salió muy mal herido de un balazo que le dieron en la boca y mano, según certificación del maestro de campo y gobernador de dicha plaza don Diego Pachecos" (AGI, Indiferente, 135,N.200).

Por esta certificación, podemos deducir que a finales de 1686 todavía se encontraba en Melilla. Su sucesor en el gobierno llegaba a esta plaza en abril de 1687.

En 1694 se le concedía la alcaldía mayor de la provincia de Verapaz, en Guatemala. Coincidía su llegada con el intento por parte de la Audiencia, siguiendo lo ordenado por el rey, de reducir a los indios choles, los cuales después de cuatro años de andar reducidos y practicando la doctrina cristiana, una noche quemaron el pueblo donde estaban y se retiraron a las montañas "a idolatrar" En la entrada que en noviembre de 1695 hacía el propio presidente, el maestre de campo don Jacinto Barrios, con el fin de someterlos, "logró tan mala fortuna" que perdió la vida en ella, así como la de muchos que le acompañaban. Lo intentó de nuevo Bartolomé de Amezquita, oidor más antiguo, fracasando estrepitosamente, pues en esta ocasión resultó muerto un capitán con toda su compañía, que se componía de 100 hombres, y los dos frailes dominicos que le acompañaban, además de perderse los casi 500 indios que llevaban "que con la fatiga de conducir más de 70 leguas los bastimentos para los soldados, murieron todos" (AGI, Indiferente, 134, N.57).

El nuevo presidente don Gabriel Sánchez de Berrope, viendo lo dificultoso y costoso que resultaba el intentar reducirlos, suspendió estas entradas y decidió centrarse en la provincia de Verapaz, en cuyas cercanías se sabía que había indios choles. Sabiendo que en ella estaba de alcalde mayor don Diego Pacheco, al que conocía por haber viajado con él y tenía noticias de su celo y aplicación, le encomendó su conquista. Dos años le costó a don Diego reducirlos, durante los cuales, junto con la gente que le acompañaban "no habitaron en población" andando todo el tiempo tras ellos por montes y tierras inhóspitas. Regresó trayendo consigo a casi 300 de los indios rebeldes, de todas las edades y sexo, llevándolos al pueblo de Belén, fundado en el valle de Urran, donde fueron recibidos por fray José Ángel Zenoyo, "ministro de la nación de indios choles" (AGI, 134, N.57).

Como durante este tiempo que anduvo fuera de Verapaz se le había vencido el plazo de tres años concedidos para su gobierno, en enero de 1698 solicitaba al monarca que se lo prorrogase por otros tres, o al menos por dos años, tiempo que había empleado en dicha conquista. Debió ser atendida su petición, pues hasta 1703 no se le tomaba residencia de su mandato (AGI, Escribanía 351B). 


\section{Francisco López Moreno}

Se encontró en la conquista de la isla de Alhucemas el 28 de agosto de 1673, cuando la tomó el príncipe de Montesarchio, acción por la que se le concedería el grado de capitán, siendo nombrado gobernador de esa plaza, (Estrada,1798, p.554-584). A primeros de noviembre de 1678 lo vimos llegar desde Málaga con refuerzos para la plaza de Melilla, regresando al poco a España para ir a la Corte a llevar las impresiones que junto con el gobernador Frías había recogido sobre las fortificaciones de esta plaza, y la necesidad de reformarlas (Gaceta, 1678b).

En abril de 1687 llegaba a Melilla para suceder en el gobierno a Diego Pacheco y Arce En este año padeció la plaza un riguroso sitio, perdiéndose los fuertes de San Pedro y de Santo Tomás. En una salida realizada el 5 de octubre para socorrer a este último, mataron a don Francisco de un tiro en la cabeza, quedando como interino el maestre de campo del tercio Viejo de la Armada don Antonio Domínguez de Dura (Morales, 1995, pp.77-78).

\section{Bernabé Ramos de Miranda}

Para ocupar el gobierno vacante dejado por Francisco López Moreno, se nombraba al maestre de campo don Bernabé Ramos de Miranda.

Había ingresado en la Armada real en julio de 1649 con plaza sencilla de soldado, en la que sirvió durante tres años, al cabo de los cuales ascendió a cabo de escuadra principal, estando de guarnición en el presidio de San Sebastián, y participando en el ataque a la ría de Burdeos. En diciembre de 1653 el barón de Vattiville, gobernador de Armas de la provincia de Guipúzcoa le daba licencia para poder marchar a su casa. "a negocios que requerían su presencia” (AGI, Indiferente, 122, N.110).

En junio de 1660 se incorpora al Ejercito de Extremadura, donde tras ocho años de servicios como soldado de plaza sencilla, asciende a alférez, sirviendo en la compañía del maestre de campo don Francisco de Alarcón, conde de Torres Bedras, desempeñando en varias ocasiones, a partir del año 1669 funciones de capitán de infantería de una de las compañías del tercio del maestre de campo don Luis de Frías, siendo as-

En la relación de méritos y servicios que presenta en 1670, se van anotando los sueldos que cobraba en cada empleo: de Cabo, tenía asignado un sueldo de 2 escudos al mes; de Alférez 15; interino de Capitán vivo, 40; de Capitán reformado 25; interino de Sargento mayor vivo 65; de Sargento mayor reformado 40. 
cendido a capitán ese mismo año) ${ }^{32}$, siendo designado interinamente por el marqués de Caracena, capital general de dicho Ejercito, como sargento mayor del Tercio que mandó formar su majestad al maestre de campo Julián Dávila, sacando gente de las compañías sueltas que iban de socorro, de los partidos de la provincia de Extremadura. Pasó luego a servir en la compañía del maestre de campo conde de Frixiliana, del Tercio Provincial de Toledo, permaneciendo de guarnición en Cartagena durante dicho año 1669.

En el trascurso de esos pasados años, durante la guerra con Portugal, se señaló principalmente en la toma de Ronches y su fortificación, en los ataques y toma del castillo de Alconchel en diciembre de 1661, de donde salió herido de dos balazos, "que el uno le atravesó el brazo derecho y el otro le hirió en la mano izquierda y en el cuerpo" (AGI, 122, N.110). Participó en el asalto y toma de la villa de Borba en mayo de 1662, y el que se dio al mes siguiente, el día del Corpus, a la plaza de Iurumeña, "donde fue quemado y volado en los hornillos hechos en la estacada que tendían los enemigos" (AGI, 122, N.110). A finales de ese mismo mes de junio se encontró en el asalto de Villabuin, y en el de la villa de Ocrato. Al año siguiente toma parte en los ataques, sitio y toma de Évora, resultando nuevamente herido, esta vez de un mosquetazo en la cabeza, en la toma de esta ciudad. Llegado frente a ella el ejército portugués, don Juan decide retirar el suyo a Badajoz, dejando guarnecida la plaza, y en el encuentro que tuvieron los Ejércitos, junto a Estremoz, don Bernabé, no repuesto de la anterior, salió herido en la cara. El 17 de junio de 1665 se encuentra en el sitio de Villaviciosa, participando en la batalla que se dio en Montesclaros, donde serían derrotados por las tropas portuguesas.

En marzo de 1671 pasaba a la Corte, sentando plaza en el Regimiento de la Guardia, en una de las compañías del mismo que mandaba el capitán de caballos corazas don Sebastián de Figueroa, bajo el mando del cual había hecho casi toda la campaña de Portugal, en cuyo destino se encontraba el 13 de julio de $16744^{33}$. [11]

A partir de esta fecha desconocemos el devenir de Miranda, que tal vez seguiría el del capitán Figueroa. Esta compañía de Figueroa sirvió después en la Armada del Océano, y en el ejército de Sicilia, en cuyo reino sería Figueroa nombrado gobernador del principado de la Sala de Partinico, cargo que ejercería hasta la ocupación de Mesina en 1678, en que pasó a España ${ }^{34}$.

AGI. Indiferente, 124, N.108.

AGI. Indiferente, 127, N.25. 
Según Estrada, en 1688 mandando el Tercio de la Costa, se le nombraba gobernador de Melilla. Al año siguiente, por el mes de octubre los moros pusieron sitio a la Plaza, "del cual fueron desengañados por el valor de los defensores y los repetidos socorros que se les envió" (Armendáriz, 1689), retirándose a sus ataques desde donde tenían constantemente vigilada la plaza. El 24 de este mes todavía mantenían el sitio, pues se sabe que ese día salió la fragata de la Plaza con la intención de capturar algún prisionero que pudiese informar de las intenciones que tenían los sitiadores. Desembarcaron en el Atalayón y fueron vistos por los moros que se echaron sobre

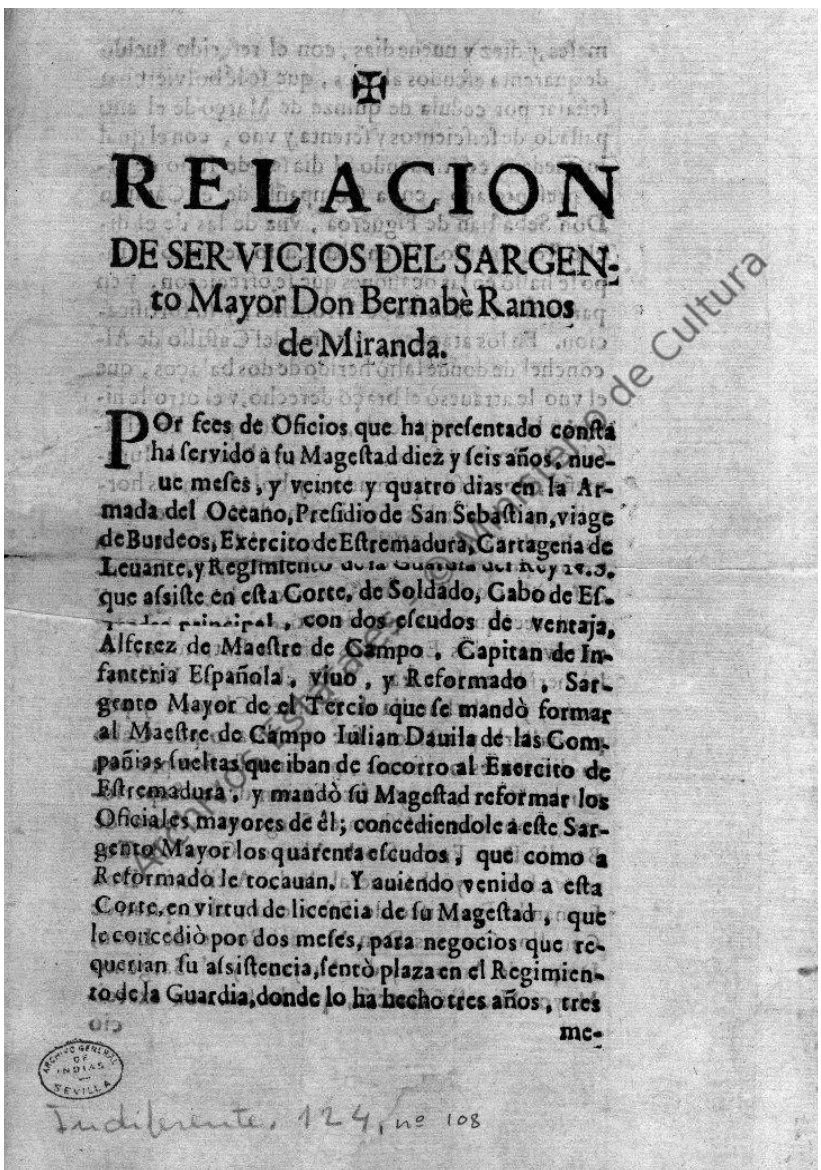

Fig.11. Relación de Servicios de Ramos Miranda. AGI Indiferente124, N.108.

ellos, causándoles cinco muertos, que no se pudieron recoger y quedaron en campo enemigo. (Morales, 1995, p.80) $)^{35}$.

\footnotetext{
Aqui se cita a Ramos Miranda como "general de la artillería", dando pie a que en las referencias sobre este gobernador se le atribuya el empleo de "general de artillería", que no nos parecía muy acorde con su trayectoria profesional. El gobernador de la plaza, era general de la artillería de la misma. El gobernador Domingo de la Canal, que era maestre de campo de infantería, en el tiempo que está en la Plaza reclama constantemente "que se le sitúe" el sueldo de general de la artillería. Cuando cesó en el cargo pasó a la Península a mandar un Tercio, como tal maestre de campo. Igual ocurre con Antonio de Zúñiga al que su hermano Francisco cita como general de artillería y gobernador de Melilla, cuando al igual que los anteriores también era maestre de campo, de caballería
} 
En marzo de 1692, volvieron a sitiar la Plaza, logrando la guarnición destruir enteramente el ataque más cercano a ella, tras lo cual desistieron en ello y marcharon a reforzar las tropas que tenían puesto sitio a la plaza de Ceuta (Alcaide, 1831, p240). En tiempos de este gobernador se excavó el foso de Hornabeque y se modificó esa parte del recinto.

\section{Antonio de Zúñiga y de la Cerda}

A Bernabé Ramos de Miranda le sucedió en el cargo el maestre de campo don Antonio de Zúñiga Medrano y de la Cerda, "caballero ilustre y muy lucido, y aunque no se explicaba bien con palabras, se hacía conocer mejor con las obras, era reputado por oficial de capacidad, conducta y valor, y demás circunstancias que constituyen un buen general, pero más que todo brillaba en su persona las ventajas de la devoción y charidad por cuias virtudes era conocido de todos, y mucho más de los necesitados de socorro" (Correa da Franca, p.207).

Era hijo de don Eugenio de Zúñiga de la Cerda y Liébana, IX señor de Villoria, quinto nieto del I duque de Béjar, y de doña Ana Cantos Royo y Villodre, de cuyo matrimonio tuvieron a Eugenio, que sería nombrado en 1717 marqués de Villora; Rodrigo, caballerizo de Su Majestad; dicho Antonio; Luis, capitán de caballos, sargento mayor de uno de los Tercios de caballería de Flandes; Cristóbal, capitán de infantería, y José. [12]

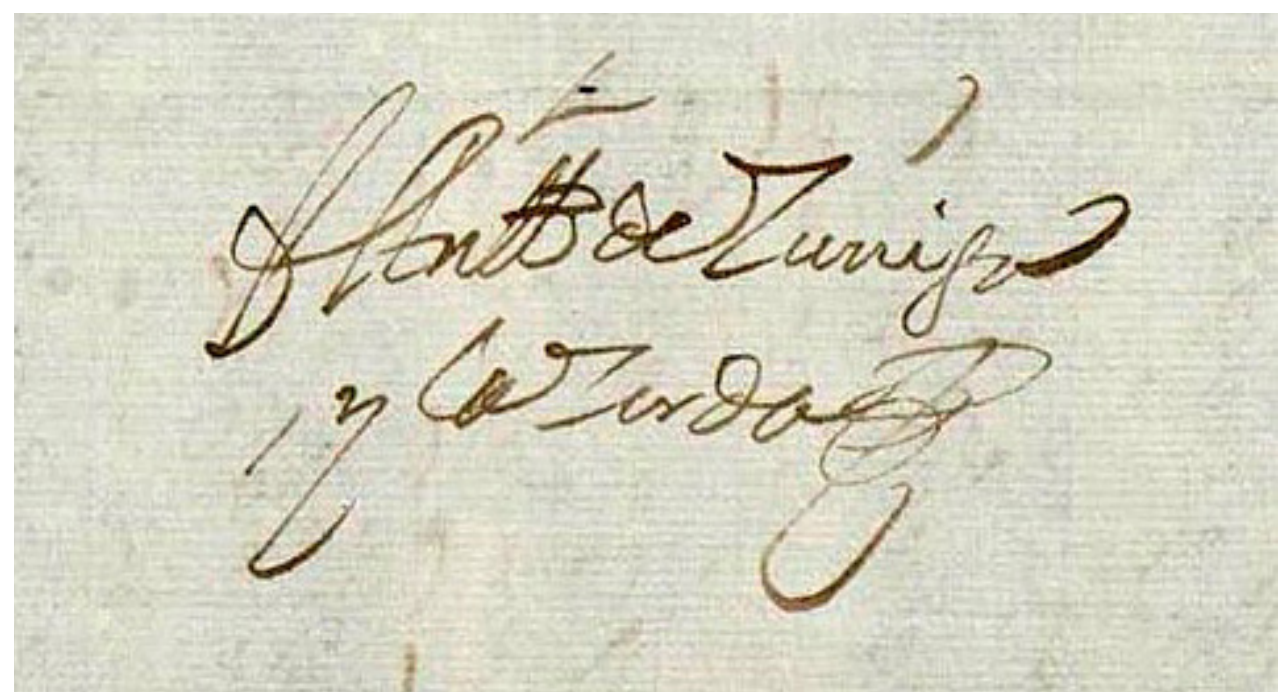

Fig.12. Firma de Antonio de Zúñiga y la Zerda AHN Diversos-Colecciones 175, N.10. 
Antonio y sus hermanos, "habiendo nacido con sangre de la casa de Villora" 36 estaban emparentados por tanto con don Manuel Diego López de Zúñiga Mendoza Sotomayor, X duque de Béjar, bajo cuya protección hicieron parte de su carrera militar en Flandes. Empezó a servir hacia 1656 pasando, según el mismo decía, "por todos los puestos de soldado, alférez y reformado, alférez de maestre de campo, capitán de infantería, capitán de caballos, sargento mayor y últimamente de maestre de campo de caballería, por lo que a pesar de sus pocas canas y años, tenía ya, (en abril de 1685), veintinueve años de servicios, de los cuales diecinueve de ellos habían sido en esos países" (AHN, 175, N.10)

José, que servía en el ejército de Flandes, llevaba ya en noviembre de 1685 seis años de capitán reformado, es decir sin mando efectivo, de una compañía y sin cobrar el sueldo correspondiente, y en esa fecha su hermano Luis se quejaba al duque de que a pesar de haber quedado vacante en el Tercio de su hermano Antonio la compañía de don Pedro de Olivera, el gobernador les había hecho la injusticia de no dársela, "y no esperaban nada de este señor pues habiéndose proveído siete compañías de infantería, no ha sido para darle una a mi hermano Rodrigo" (AHN, OSUNA, CT.102, D.13) $)^{37}$.

En abril de este año 1685 recién ascendido a maestre de campo de caballería, la noche del domingo de Ramos, encontrándose en la ciudad belga de Aurdinarde (Ourdenaarde), recibía la orden de pasar de guarnición con su tercio a la villa de Atha, de lo que daba noticias al duque y le decía que "lo hacía con el mismo desconsuelo con que se había marchado el Tercio de su excelencia ${ }^{38}$, que era sin haber cobrado la paga, que se le debía desde el mes pasado, y se atrevía a decirle que los dos Tercios iban a sufrir su ausencia". A finales de mes como seguían sin cobrar y todos los oficiales y él mismo se encontraban muy empeñados, se había desplazado a la ciudad de Gante con el propósito de hablar con el Intendente a fin de conseguir que se les pagasen los atrasos. Como había fallecido don Diego de Herrada, gobernador de Ostende y se debía proveer en esa Corte su vacante, le pedía al duque en otra de sus cartas

Archivo Histórico Nacional (AHN). Diversos-Colecciones, 175, N.10.

Carta de 1 de noviembre 1685.

38 El duque, que habia iniciado su carrera militar en el ejército de Flandes donde estuvo sirviendo desde 1681, firmada la paz con Francia, paso a España en 1684, en donde estuvo hasta 1686 en que partió para ir a reforzar los ejércitos del Emperador Leopoldo I de Austria en su lucha contra los turcos, muriendo eses mismo año en el asalto a Budapest. 
que le favoreciese en ello, así como en la de obtener el mando de uno los tercios que vacasen en ese país o en Italia ${ }^{39}$. [13]

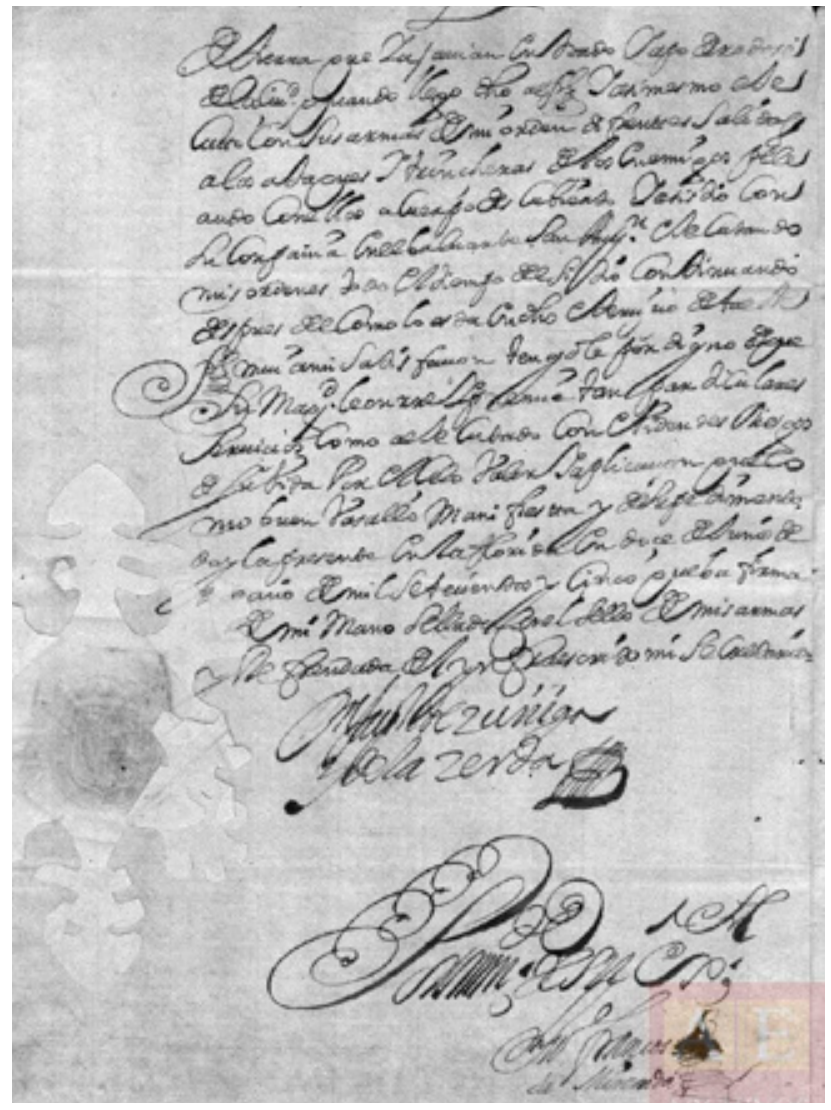

Fig. 13. Firma y sello de fosé de Zúñiga y de la Cerda. AGI Indiferente 136, N. 192 .

En una de las cartas que su hermano Luis, que le debe acompañar en su traslado, escribe al duque, le decía que la villa de Atha era pequeña, muy razonablemente fortificada, pero muy mal guarnecida pues solo había poco más de 200 alemanes del regimiento de Baden y del barón de Otel, así como el tercio de caballería de Odemón y el de su hermano, que como estaba desmontado estaba guardando una de las puertas de la villa ${ }^{40}$. La última correspondencia con el duque que conocemos es de 9 de marzo de 1686, fecha en la que seguían, Antonio y Luis, de guarnición en Atha. Su protector, el duque, fallecía a mediados de julio de 1686 a consecuencia de una herida de bala, producida unos días antes en el asalto a Budapest.

De su nombramiento y estancia en Melilla como gobernador tan solo tenemos algunas referencias de pasada. Estrada nos dice que vino a gobernar Melilla, sin indicarnos el año, y que en su tiempo, en 1697, se empezó a fabricar el fuerte de Santiago. En mayo de 1698 don Antonio decía que hacía 38 años que servía a su majestad, y que últimamente

Carta de 19 abril 1685. AHN. OSUNA, CT.102, D.1.

Carta de 29 mayo 1685. AHN. OSUNA, CT.102, D. 7. 
había obtenido su aprobación "del prolongado tiempo de 14 meses que duró el sitio de Melilla, que defendí, obligando a levantarle a los moros" (AHN, 175, N.10). Continuaba su relato indicando que haría un año, en los primeros meses de 1697, que su majestad se había servido enviarlo a la Plaza de Orán por Cabo Subalterno de ella, y estando ejerciendo dicho cargo, en mayo de 1698, se fugaban del Castillo de san Andrés, donde se encontraban presos, don Antonio de Leiva, y el marqués de Mariñas, que embarcaron juntos para huir de Orán, pero les cogió un temporal que hizo que don Antonio volviese al castillo. Estas fechas nos hacen deducir que al menos los últimos años de estancia de Zúñiga en Melilla debieron corresponderse con los de 1695-1696, coincidiendo con la fecha que apuntaba Estrada.

El gobernador de Orán, marqués de Casasola, encarcelaba al alcaide y demás oficiales responsables de su custodia y daba parte de lo sucedido al Consejo de Guerra. Celebrado el mismo, el marqués de Oropesa, uno de sus miembros, decía que el Sargento Mayor de Batalla, subalterno de aquella plaza era también culpable de la fuga y que habría que sacarle de aquel empleo, y mientras tanto se dilucidada si tenía mayor culpa, había que mandarle que se presentase lo antes posible en la Alhambra de Granada, opinando lo mismo el marqués de Villafranca. El conde de Frigiliana decía que se le debía suspender unos días de su empleo para que quedase enseñado y advertidos los que le sucediesen, acompañando esto con una severísima reprensión. Su majestad de acuerdo con el Consejo mandó que don Antonio se presentase en la Alhambra, y nombraba en su lugar al maestre de campo don Gaspar de Ocio. [14].

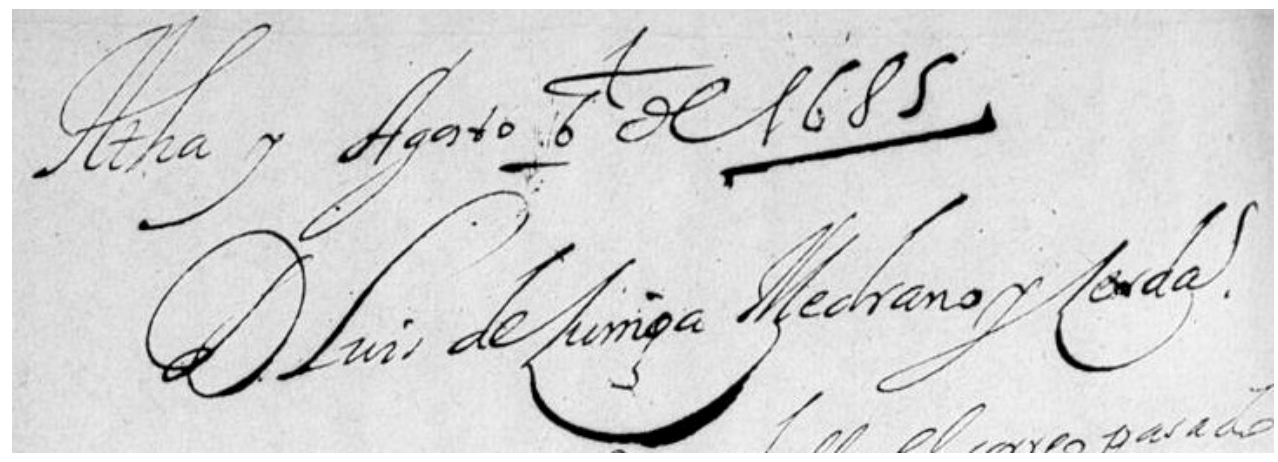

Fig. 14. Firma de Luis de Zúñiga Medrano y Zerda. AHN Osuna CT102, D.10. 
En relación a este suceso don Antonio había tenido cierto desplante con el gobernador, cuando éste le ordenó que fuese a prender a un criado de don Antonio de Leiva que no quería abandonar la cárcel donde se encontraba su señor. Zúñiga le contestó que lo excusase de ello pues su puesto no era para ir a aprender criados, y habiéndoselo mandado por segunda vez, fue a ejecutar lo ordenado, pero viendo que Leiva se oponía enérgicamente a que se llevasen a su criado y no abría la puerta de su celda, don Antonio para evitar males mayores desistió de ello, desobedeciendo la orden que se le había dado, de lo cual informó al gobernador, y éste le instó a que le diese el informe por escrito. Al parecer se haría caso al conde de Frigilana y la cosa no debió pasar a mayores pues pasado el tiempo, el 30 de enero de 1699, siendo ya maestre de campo, el rey Carlos II nombraba a don Antonio gobernador de la Florida, no llegando a la ciudad de San Agustín hasta al menos el cinco enero de 1700, tiempo en el que vemos que su antecesor don Laureano de Torres Ayala todavía está desempeñando el cargo de gobernador. A principios de noviembre de 1702 empezaba el sitio de la plaza de San Agustín, capital de la provincia, que durante dos meses "el gobernador de San Jorge con muchos indios infieles y 500 ingleses les puso por mar y tierra", el cual tuvieron que levantar ante la resistencia que se les hizo y la llegada del socorro que se enviaba desde la Habana. A primeros de marzo de 1704 sigue firmando sus escritos con el título de gobernador de la Florida, pero añade el de gobernador electo de Cartagena de Indias. El 4 de julio de este mismo año, nombraba al capitán don Bernardo Nieto de Carvajal para que continuase vigilando diariamente las obras de fortificación que se estaban haciendo, pues él, que lo había hecho hasta ahora, no podía seguir haciéndolo tan continuo por las obligaciones de su cargo. Había tenido noticias de que los enemigos de Carolina se aprestaban para venir nuevamente con mayores fuerzas artillería para tomar la plaza, y por ello había dispuesto que se construyesen seis fortines y una trinchera que los uniese, formando todo una línea de unos 1.300 metros frente a la plaza, para estorbar con ello la entrada por la parte de tierra. Como los hacía de madera, había escrito al Consejo pidiendo poder construirlos de piedra, que era fácil de extraer en las cercanías y de llevar al sitio en carretones, a lo que se le contestaba "que siguiera haciéndolos de madera, que había mucha". Esta respuesta del Consejo está fechada el 30 de junio de 1705, en que seguía como gobernador de la Florida ${ }^{41}$.

41 En mayo de 1703, durante el sitio de Ceuta, en la salida que se hizo contra los sitiadores el día 18 de dicho mes se distinguía en ella don Antonio de Zúniga, general de batalla 


\section{Domingo de Canal y Soldevila}

Por enero de 1697, habiendo su majestad nombrado teniente del gobernador de la plaza de Orán a don Antonio de Zúñiga, se nombraba para ocupar su vacante al maestre de campo don Domingo de Canal y Soldevila, catalán ${ }^{42}$, nacido al parecer en Cerdaña, que se encuentra ya en Melilla el 10 de febrero de 1697.

De los años anteriores a su llegada a esta plaza, apenas tenemos datos suyos, tan solo conocemos que en 1656 un Domingo Canal de Soldevila, capitán, pedía una recomendación para presentarla ante el Consejo de Guerra, y un caballo ${ }^{43}$, que por las fechas podría tratarse de nuestro gobernador ${ }^{44}$.

Desde su llegada a Melilla va a mantener correspondencia con don Juan de Dios Silva Mendoza, X duque del Infantado. En ella le va a ir informando sobre todo de los asuntos concernientes al gobierno de la Plaza, de la evolución de las obras de defensa y mejoras de instalaciones que iba realizando, dándole también noticias de todo lo concerniente a su abastecimiento, asunto que le tenía muy preocupado ante las repetidas veces que llegaban a agotarse las existencias, problema sobre el que insiste advirtiendo la necesidad que había de contar con reservas al menos para varios meses, pues de lo contrario dependían de una serie de causalidades- el tiempo, la existencia de navíos en Málaga, el asalto de corsarios- que cualquier día producirían una desgracia. Se queja repetidamente de lo tarde y mal con que llegaban los socorros, retraso y faltas que achacaba a la inoperancia del asentista. En estas cartas que escribía al duque, intercala comentarios de carácter personal, que nos sirven para entrever su estado de ánimo y las dificultades que padecía para poder tenerlo todo a punto y prevenido ante la constante amenaza de que en cualquier momento se presentasen los enemigos con la intención de asediarlos. No solo sufrían las plazas en sí el abandono por falta de medios ante la pobreza en que se encontraba la monarquía, sino que

\footnotetext{
y cabo subalterno de dicha plaza. BAUER (1922), p.37. Suponemos se trata de otro personaje homónimo de nuestro gobernador.

PEÑA (1709), p.514.

Archivo de la Corona de Aragón (ACA). Consejo de Aragón, Legajos, 0310, no 067.

No hay que confundirlo con Domingo de Canal y Torrella, coetáneo suyo, gobernador de Ibiza (1698-1704). En una semblanza de este último se dice equivocadamente, y luego repiten otros autores, que habia sido gobernador de la plaza de Melilla. ESPINO (2000), p. 47.
} 
la miseria y el hambre alcanzaban a sus sufridos pobladores. En varias ocasiones sus quejas son referentes a ello, pues estando ya cerca de cesar en su cargo, después de cinco años y seis meses, todavía no había cobrado de su sueldo un solo maravedí, y sus súplicas se repiten para que por favor lo sacasen de allí. [15]

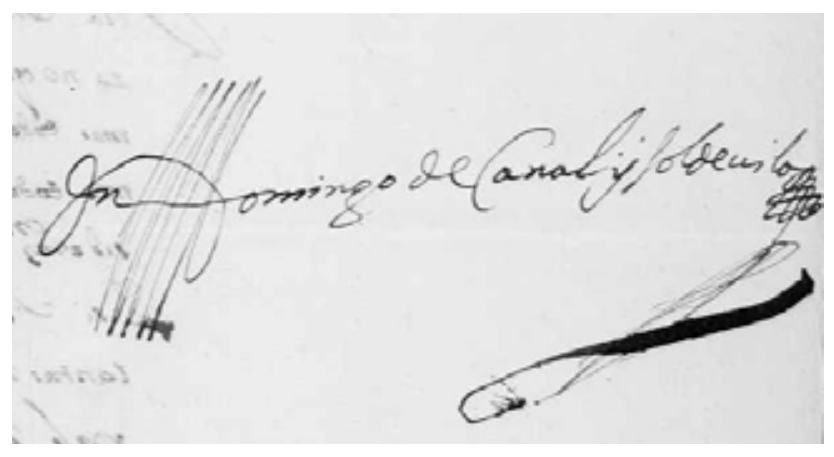

Fig. 15. Firma de Domingo de Canal y Soldevila. AHN Osuna 36, D. 5.

Como indicábamos, el nuevo gobernador ya se encontraba en Melilla en febrero de 1697, según deducimos por lo que leemos en la relación de servicios de su sobrino Juan de la Canal y Soldevila, que le debía acompañar. Decía que el día 10 de ese mes de febrero había sentado plaza en la compañía del pie fijo que mandaba el capitán Bartolomé de Medellín.

A su llegada, la Plaza había perdido y dejada por inútil, toda su línea avanzada de defensa, estando todos los fuertes que la componía arrasado: Santo Tomás o de la Cantera, San Francisco, Santiago, San Lorenzo, San Pedro o de la Albarrada y San Miguel o de la Huerta Grande, encontrándose así mismo falta de almacenes para tener la munición en lugar seguro y a cubierto del posible fuego de la artillería enemiga, con los aljibes del agua igualmente poco protegidos. Según indicábamos estos fuertes exteriores, en realidad simple atalayas, alejados de las defensas principales, cuya lejanía tenía como consecuencia un ineficaz apoyo por parte de la artillería y fusilería de la plaza, resultaron poco efectivos y dificultosos de mantener, tal como había quedado demostrado en los pasados años. Ya en tiempos del gobernador Frías se había pensado en la necesidad de disponer de otro tipo de defensas más efectivas, pues como éste señalaba no eran más que unas simples torres de piedra y barro, sin flancos, sin estrada cubierta, y que solo servían para otear el Campo ${ }^{45}$, empezándose a finales de su mandato, bajo la dirección del ingeniero Octavio Meni, a reforzar las

45 GACETA (1679c), p.304. 
defensas principales de la plaza, iniciándose la excavación del foso de la Alafia, refuerzos que fueron continuados por el gobernador Miranda, que excavaría el foso de Hornabeque y modificaba esta parte del recinto.

Ante el empleo cada vez más numeroso de la artillería y de la técnica del minado por parte de los moros, que empiezan a ser dirigidos e instruidos por ingenieros extranjeros, al menos franceses ${ }^{46}$, se decide abandonar este sistema de defensa que había quedado ya obsoleto y resultaba casi inútil ante un ataque de estas características. Siguiendo con la tarea de sus antecesores de reparar y mejorar las defensas, al poco de su llegada iniciaba la construcción del fuerte de Santiago, en la punta oriental del tercer recinto, bajo el padrón que dominaba la plaza, siguiéndose ya en su trazado las técnicas de fortificación abaluartadas. Con ellas va a reforzar todo el frente de muralla desde la torre de San José, que terminará y modificará, hasta dicho fuerte de Santiago, como se puede apreciar en el plano del alférez Alfonso Diez de Aux.

A su llegada, las obras del nuevo fuerte de Santiago ya debían estar iniciadas, pues a final de abril, apenas dos meses después de su llegada, ya está en condiciones de albergar una guarnición, y con la obra suficientemente avanzada para poder mantener el asalto que esa noche por varias veces le dieron los moros (Morales, 1995, p. 84-85).

Según decía en una de sus cartas a mediados de marzo de 1699, tras dos años de trabajos, ya tenía acabado los almacenes para la munición y víveres que había empezado el día en que llegó a la plaza. Se habían construido a prueba de bombas, por tener más de treinta y cinco pies de peña viva encima. El almacén de las municiones tenía capacidad para cuatro mil quintales de pólvora, seis mil bombas y otras tantas granadas, en el de los víveres cabía género para seis meses, "y son los mejores almacenes que le rey tiene en sus dominios" (Carta de 15/3/1699. AHN, OSUNA, CT.36, D.1). Se había acabado también de fortificar y terraplenar los aljibes del agua. En esta fecha tenía terminada la mina real, con lo cual, decía que ya tenía todas las fortificaciones exteriores contraminadas. Avisaba también de que iba a empezar un puente para la comunicación con las obras exteriores.

Por el mes de abril de este año ya debe estar finalizado el fuerte de Santiago, que se ha convertido en la parte mejor cubierta y fortificada de

46 GACETA (1678c), p.232-232v. 
la Plaza, y por eso en mayo, en una de las acostumbradas negociaciones que solicitaban los moros para rescatar e intercambiar esclavos, les hace pasar a este fuerte, para que no reconociesen las faltas de las fortificaciones.

El siete de enero de ese 1699, después de haber estado la plaza todo un mes sin poder comer de caliente por falta de leña, de manera que los soldados tenía unas caras que no se les reconocía, comunicaba que había llegado una gabarra cargada con ella, y que así mismo había llegado otro navío al día siguiente, pequeño como una cascara de nuez, cargado con alimentos, y suponemos que enfadado por ello, criticaba al asentista diciendo que éste cumplía su obligación con maña, para que el rey y el Consejo se creyesen que con un navío que había enviado estaría la Plaza abastecida, cuando tan solo habían llegado 100 sacos de harina, 114 quintales de bizcocho y 30 de bacalao, además de un poco de pólvora y unos tablones para arreglos de la artillería. Se quejaba al duque de lo mal que se le trataba después de veintitrés años de servicio y con treinta heridas que padecía, porque no se le concedía la patente de general de batalla que había solicitado a su majestad, cuando este ascenso se lo habían concedido a otros antecesores suyos en el cargo, y no entendía como a él no se le concedía "que la sangre que he derramado en tanta herida debo de creer merecerá alguna atención" (Carta de 15/3/1699).

En mayo, como vimos, daba noticias de que los moros se habían acercado a la plaza con bandera de paz con el fin de tratar sobre el intercambio de esclavos que había en la Plaza por prisioneros que ellos tenían en Mequinenza, a lo que estaba de acuerdo siempre que enviasen a alguien para que tratase su precio con los dueños de dichos esclavos. Después de salir a tratar con ellos el veedor y un capitán, regresaron con una carta escrita en árabe, que no supo leerla bien ni el intérprete que traían ni el que había en la plaza, así que la enviaron al Consejo para que el maestro de lenguas la interpretase, aunque pudieron entender que se les pedía el nombre de los esclavos y de que lugares eran. Les contestó con una carta escrita en español en las que les daba los datos que pedían, "y todo esto a fin de que por este camino podré atraer algún confidente en la Plaza que nos diga lo fuerte y lo flaco de sus fuerzas" (Carta de 6/6/1699. AHN, OSUNA, CT.36, D.2). A finales de este mes de mayo, andaba la plaza falta de pan, que apenas tenían para doce días, y ante la tardanza de la embarcación que había de llegar de Málaga, a pesar del buen tiempo que habían tenido, envió el barcolongo de dotación con el ayudante José Paredes a dar aviso para que se le socorriese. Cuatro días después llegaba la saetía que esperaban, cargada de provisiones de 
boca y guerra, que había estado durante diecinueve días huyendo de los corsarios que la perseguían. Se lamentaba de que no se hacía caso a su petición de tener en la plaza provisiones de reserva al menos para tres meses, pues cualquier accidente o perdida de las embarcaciones de suministro, podría hacer que se perdiese la Plaza, "y lo que no han podido conseguir los enemigos a fuerza de las armas lo lograran por hambre" (Carta de 6/6/1699).

En estos meses estuvieron los moros tranquilos, tan solo disparando de vez en cuando algunos tiros a la plaza, pero a primeros de junio de 1700 , teniendo noticias por dos desertores de que se iban a comenzar las obras de fortificación del baluarte de San José, ocuparon tres ramales de los avances que tenían cercanos al mismo. La tarde del día dos, a las siete y media, salió el gobernador con tres columnas de infantería a intentar desalojarlos, pero los moros que tenían allí concentrada tropas de caballería e infantería, las rechazaron con esfuerzo, y tuvo que mandar salir a la gente que tenía preparada de reserva, logrando al fin desalojarlos de sus posiciones. Esa noche no tuvieron ningún muerto, tan solo cinco heridos, y como posteriormente comunicaba, sospechaba que por parte de los moros sí que habían sufrido algún daño, pues llevaban ya casi dos meses muy quietos, y además no había retirado a sus muertos, en lo que normalmente ponían mucho empeño, para que no se viesen las bajas que se le producían.

El 10 de julio de este año 1700 llegaba un barco cargado con un poco de harina, menestras, tocino, vaca, aceita, vinagre y vino que, como siempre, llegaba cuando ya se tenían agotadas todas las provisiones, quedándoles tan solo pan para cinco días. Unos días después dos galeras que pasaban hacia Orán, les daba un poco de bizcocho y bacalao, y algunas menestras, aceite y vinagre. "que a no habernos socorrido con estos dos pistos, que fue providencia de Dios el que llegase, ya esto estuviera de otro amo, y nosotros hubiéramos dado gracias a Dios" (Carta de 30/7/1700. AHN, OSUNA, CT.36, D.4). Durante este mes no dejaron de llegar auxilios a la Plaza, así el día veintiuno llegaba una saetía cargada con provisiones, y al día siguiente una gabarra cargada de leña y un pingue cargado de cal, y otra saetía cargada de leña el día treinta. A pesar de ello el gobernador insistía en que si no se tenían víveres almacenados para tres meses, cualquier día aquello se perdería sin remedio alguno.

Para finales de julio ya tenía hecho los cimientos de la obra del baluarte de San José, y más de la mitad de la nueva muralla, de manera, según decía, que ahora no sería tan fácil que el mar se lo llevase como 
ya había hecho antes, pues cuando se hizo, por ahorrar materiales, no se había hecho lo suficientemente fuerte.

Al final de esta carta que había escrito al duque el 30 de julio dándole noticias de lo sucedido en esos meses, iniciaba el párrafo diciéndole: "Señor el desgraciado siempre enfadoso y siéndolo yo tanto, no extrañará lo sea" (Carta de 30/7/1700) y pasaba a quejarse nuevamente de que no había sido atendida su petición para que le asignasen sueldo de General de Artillería. En su enfado llegaba a decir que a él se le había negado "siendo así que cualquier militar que se retirase de un Ejército por no servir más al Rey, figurándose un achaque encubierto, se lo dan" (Carta de 30/7/1700). Se lamentaba de que no había razón para que se le dejase morir de hambre, pues desde que estaba en Melilla, y en estas fechas ya llevaba más de dos años, no había cobrado ni un maravedí, por lo que suplicaba a su excelencia que le protegiese para poder conseguir lo que pedía.

El nueve de septiembre tiene pocas novedades que comunicarle, le decía que los enemigos seguían tranquilos y tan solo de vez en cuando disparaban algunos tiros "para darnos a entender que están en su ataque" (Carta de 9/9/1700. AHN, OSUNA, CT.36, D5), y que iba prosiguiendo la obra del baluarte. Aprovecha para insistir en la necesidad de tener almacenados suficientes víveres, pues aseguraba que un día u otros aquello se perdería por hambre. Nuevamente le comentaba que el día que llegó la embarcación con alimentos desde Málaga, ya tenían aprestado el bergantín de la Plaza para ir a solicitar socorros, pues lo tenían todo acabado, tan solo quedaba algo de pan, y añadía "si en verano padecemos todas estas necesidades dejo a la gran consideración de VE que sucederá en invierno" (Carta de 9/9/1700), refiriéndose al mal tiempo para la navegación. Acababa la misiva comentándole que había vuelto a mandar una petición al rey sobre el asunto de su sueldo, que en tres años y medio que llevaba en esa Plaza, no había cobrado un maravedí y se estaba muriendo de hambre.

A finales de octubre repetía las noticias de que los enemigos se mantenían en sus posiciones y que él continuaba el baluarte sin impedimento alguno. Le había llegado aviso desde Málaga de que los moros estaban preparados para sitiar el Peñón, y él pensaba, que si hacían lo que ya habían hecho otras veces cuando se había corrido la voz de que iban a sitiar el Peñón, cuando en realidad los preparativos eran para sitiar esta Plaza, que tal vez esta vez fuese lo mismo, por lo que él se encontraba en su puesto con toda vigilancia, "y si viniesen procuraremos hacer todo lo que da de sí el arte y el paraje en que me hallo" (Carta de 22/10/1700. 
AHN, OSUNA, CT.38, D.6). El 23 de este mes de octubre, habiéndose posicionado algunos moros en sus líneas de ataques, mandó salir tres columnas de cincuenta hombres cada una al mando de sus capitanes, Diego Cosido, Juan de Salas y Bartolomé Medellín, previniendo otras tropas para cubrirles la retirada, con el fin de capturar algunos prisioneros para poder interrogarlos sobre sus intenciones, "pero como estos moros son tan bárbaros que primeramente se dejan matar que no rendirse" (Carta de 22/10/1700), tan solo trajeron un prisionero, tan mal herido, que antes de entrar en la plaza falleció. En la retirada hacia la plaza, cargaron los moros con tanto ímpetu que mataran al capitán Cosido y a un cabo de escuadra, hiriendo a un alférez reformado y a otro cabo.

En primero de enero de 1701, su sobrino Juan de Canal ascendía a Alférez, pero con sueldo de plaza de soldado ordinario, y pasaba a la otra compañía del pie Fijo que mandaba el capitán don Francisco de Mora y Perea, en la que continuó hasta el tres de febrero de ese año en que esta compañía pasó a España a servir en uno de los Tercios de la Armada, y él se incorporó a su anterior compañía ${ }^{47}$.

En los últimos días de este mes de enero, y con el hambre ya acuciándoles, llegaban a la plaza, el veinticinco, una gabarra cargada de provisiones de boca, y al día siguiente una saetía a última hora, como siempre, pues no había manera de que el asentista cumpliesen con su obligación. Se lamentaba de que los enfermos del hospital se habían estado muriendo por falta de alimentos y medicinas. Comentaba que hacía días que desde Málaga le había escrito el asentista diciéndole que no había podido remitirles la caja de medicinas, porque no había salido ninguna embarcación hacia ese destino, y ahora que habían llegado dos de ellas, no enviaba ninguna, y socarronamente añadía "aunque sí la relación de las que tenían que enviar, para que nos consolemos con ella" (Carta de 4/2/1701. AHN, OSUNA, CT.36, D.7).

En la misma carta se quejaba de que no tenía todavía finalizada la obra del baluarte, porque ante la escasez de medios, no podían ir muchos hombres a trabajar a la vez, pues les faltaban espuertas para traer los materiales y madera para reponer los astiles de los picos con que arrancar la piedra "y esta cosa de tan poca monta no hay forma de que lo remitan" (Carta de 4/4/1701). Esta penuria de materiales se la achacaba al veedor Juan Ginés de Cabrera, al que reprochaba que no le enviara las cosas

AGI. Indiferente, 139, N.18. 
que necesitaba cuando se las pedía, sino cuando a aquel se le antojaba. El enemigo se mantenía tranquilo en sus posiciones, y hacía algunos días que no habían disparado tiro alguno. Al final, agradece al duque que esté intercediendo para resolver su petición sobre la concesión del sueldo de general de la artillería. Terminada ya la carta anotaba al dorso de ella que ese día, cuatro de febrero, había llegado otra saetía con alimentos, y que en ella traían la caja de las medicinas "conque ya parece que los ministros de Málaga se conocen mortales” (Carta de 4/2/1701).

Después de estos años de gobierno, don Domingo parece estar hastiado del abandono en que le tienen, pues en una de las cartas que enviaba al duque, le agradecía otra de éste fechada en 5 de abril, en la que al parecer le comentaba algo sobre su petición de nuevo destino, pues le decía "espero en Dios que por medio de vuestra excelencia he de salir con alguna conveniencia, en la parte que vuestra excelencia gustase, como no sea retaguardia, que yo no deseo, sino frontera o ejército, que cuatro años de África valen por guarda de un ejército" (Carta 13/5/1701. AHN, OSUNA, CT.36, D.8).

A finales de abril con la llegada de una embarcación cargada de alimentos, recibía aviso desde Málaga que para la próxima se le enviarían pertrechos de guerra. Esperaba que el marqués de Leganés, al que se le había nombrado capitán general de las Costas de Andalucía, con su gran celo, dispusiera que todas estas fronteras estuviesen como debieran estar para poder hacer frente a cualquier contratiempo "y poder hacer aquella defensa honrada que se debe" (Carta de 13/5/1701).

En las novedades que le daba en mayo le comunicaba que había muy poca gente del enemigo en ese Campo, porque su rey había recogido la mayor parte de las tropas de sus fronteras, reuniendo un ejército de 150.000 hombres, marchado a Mostagán, contra los argelinos. A pesar de que mantenían con todo cuidado sus posicione frente a la plaza, él pensaba que era la ocasión de hacer una buena salida sobre ellos, pero no lo intentaba porque no disponía de la gente necesaria, pues apenas podía reunir a doscientos hombres para esa salida.

Referente a los asuntos internos de la Plaza le informaba del grave caso de Gregorio Ximénez, clérigo desterrado, que a instancias del vicario Manuel Galindo, intentaba convencer a unos soldados para que robasen pólvora, y como no lo consiguieron lo intentaron con un artillero, que manejaba más cantidad, al que le prometieron comprarle hasta 1.000 libras de dicha pólvora. Avisado el gobernador de lo que pasaba por el propio artillero, y puestos presos a través del cura decano de la Plaza, 
recogía información testifical sobre el delito y la enviaba al Consejo y al obispo de Málaga, que era quien tenía potestad para juzgarlos. Se quejaba de que tenía allí entre frailes y clérigos seis desterrados, "y todos de la piel del diablo" (Carta de 13/5/1701), que los obispos enviaban a esos presidios para verse libre de tener que mantenerlos, que atropellaban lo que querían y no podía procesarlos ni castigarlos, y además no hacían nada en la plaza y gastaba con ellos una ración diaria.

El 31 de mayo a don Felipe Martin, sargento mayor de la Plaza, que había salido de ella a tratar del rescate de ciertos esclavos, estando en el campamento de los moros pudo entreoír noticias de que los argelinos habían derrotado a Muley Ismail, y que había dado aviso al alcaide moro del Campo que juntase la mayor parte de harina y tropa que pudiese, porque se dirigía a sitiar Melilla. Hizo llegar como pudo el aviso al gobernador, y habiéndose internado precipitadamente dicho alcaide en ejecución de las órdenes que le llegaron, se lo llevó prisionero junto con un ayudante y tres cristianos que le servían, lo cual en opinión del gobernador verificaba la noticia que se le había dado, reforzada por el hecho de que los moros habían dejado su rehén en la Plaza. Avisaba de ello al Consejo y pedía que se le enviasen 500 infantes y 200 caballos, que estos últimos a pesar de ser tan pocos, hacían allí más labor que tres mil infantes. Este refuerzo no debía retrasarse, pues si venía el rey en persona traería un gran ejército y se esforzarían en tomar la Plaza. Relataba todo esto al duque, y en vista de la amenaza de sitio, al final le decía "y en orden a lo que escribí el correo pasado, que el Rey me enviase sucesor, suplico a vuestra excelencia no hable en ello hasta ver si este sitio es o no es" (Carta de 9/6/1701. AHN, OSUNA, CT.36, D.9).

A finales de septiembre enviaba el bergantín a dar aviso a Málaga de que tenía la Plaza llena de enfermos, sin tener un bocado de pan para poder darles, tan solo tenía bizcocho seco, tocino y carne de vaca salada, y por ello se morían muchos, faltándoles también medicinas con que curarles. Esta vez se le socorre enseguida, y el seis de octubre llegaban una gabarra, una saetía y un bergantín, cargados de alimentos y trayendo medicinas.

Este mismo mes de octubre, como había visto que seguía habiendo pocos enemigos en el Campo, decidió salir con 200 hombres para ver si podían traer algún prisionero que diese noticias de porqué seguían reteniendo al sargento mayor y a los otros prisioneros. Aunque lograron apoderarse de todas las posiciones, no pudieron hacer ningún prisionero vivo "porque estos hombres son tan brutos que más estiman que les maten que no que les rindan" (Carta de 16/10/1701. AHN, OSUNA, 
CT.36, D.10). Se mantuvo en su campo más de seis horas, deshaciendo la mayor parte de la posición principal y dos ramales cercanos, hasta que fueron acudiendo a repelerlos en gran número y tuvo que retirarse. Al llegar a las cercanías del fuerte de Santiago mataron a un soldado e hirieron a otros dos, acabando la jornada sin más desgracias. Ante la necesidad de noticias, envió una fragata armada para que saltase a tierra en alguna parte de esa costa y cogiese algún prisionero. Unida con el barco de Alhucemas bajaron a tierra firme y lograron coger prisioneros a dos moros, los cuales le aseguraron que uno de los hijos de Muley Ismael se había levantado en la parte Sur del reino, y que por eso se habían retirado las tropas que había frente a los presidios, "con lo que la noticia que teníamos que venían a sitiar esta Plaza ya está desvanecida" (Carta de 16/10/1701).

Alejado el peligro, disculpándose de su insistencia, y a riesgo de resultar impertinente y molesto, no podía dejar de decir al duque lo que tantas veces le había suplicado, que ya no podía seguir tolerando el hambre y desnudez que estaba padeciendo, pues habían pasado ya cuatro años y ocho meses que estaba en la Plaza y seguía sin cobrar un solo maravedí de su sueldo, y además no se le había concedido el de general de la artillería que tantas veces había solicitado. Le rogaba que hablara a su majestad para que mandase que se le pagase, "y que se me saque de este lugar" (Carta de 16/10/1701) dándole otro puesto en alguna otra parte, Sin contar los veinticuatro años de servicio que llevaba y las treinta heridas recibidas, solo con lo que había servido en esa Plaza y lo que había trabajado en ella "que yo se la he hecho Plaza, que antes no lo era, sin costarle a su majestad nada, más que la cal que me envió" (Carta de $16 / 10 / 1701$ ), esperaba que se lo concediesen. Terminaba pidiendo que lo sacasen "de este calabozo, que ya es tiempo venga otro a probar esto lo que es" (Carta de 16/10/1701), pues ya había pasado el tiempo asignado que tenía que cumplir en su cargo.

El 26 de abril de 1702 había llegado a la Plaza una gabarra cargada de leña y un pingue cargado de bastimentos de boca y guerra, trayendo también astiles y espuertas, con lo que gracias a Dios ya tenían con que trabajar más y proseguir las obras que tenía comenzadas. Estaba acabando de profundizar el foso del fuerte de Santiago y ya había terminado de minar toda la media luna," que era la parte más flaca", teniendo ya hecho un hornillo, para que en el caso de que intentasen minarlo por aquella parte, poder él contraminarlos antes. Seguía prolongando la mina real, de la cual ya tenía noticias el enemigo y estaban intentando contraminarla pasando por debajo, y esperaba poder dar con ella para 
destruirla, para que no pudiesen seguir con este tipo de guerra, "que es la que ordinariamente suelen hacer estos bárbaros" (Carta de 9/5/1702. AHN, OSUNA, CT.36, D.11).

Le llegaba aviso desde la plaza de la Alhucemas, a la que había ido a parar la embarcación que venía a Melilla a causa del temporal, de que había llegado a esa plaza el alférez don Alonso González, con otros dos cristianos que se escaparon de Mequínez, donde hacía muchos años que estaban esclavos, y le aseguraba que el rey había ordenado poner sitio a la plaza de Melilla, noticia que le confirmaba el alférez desde Málaga, y le avisaba que dos valencianos que se habían escapado de las obras exteriores habían asegurado a Muley Ismael que le entregarían la Plaza, pues estaban en connivencia con otros de su nación que estaban en ella. Le decía al duque que estaba sobre aviso, pero como tenía en ella 70 u 80 valencianos no había podido todavía averiguar cuáles de ellos podrían ser.

Como los moros andaban entrando y saliendo de sus posiciones, en un barranco que está a media legua, donde caben veinte o treinta mil hombres sin que se les pueda ver desde la plaza, le pedía que sería conveniente que hablase con los señores del Consejo para que le enviasen 400 hombres, de gente veterana, que con ellos y con la gente que había en la plaza si llegaban a sitiarlo haría una honrada defensa, y con toda esta gente los valencianos no se atreverán a cometer la infamia que hicieron en el fuerte del Peñón, y además desde que le llegó la noticia del alférez, había mandado que no se pusiese a ninguno de ellos en las puertas ni en las posiciones avanzadas. El motivo principal de la pérdida de ese fuerte había sido el doctor Miquel Polop, que era uno de los valencianos que había echado de esta plaza enviándolo al Peñón, porque andada conjurado con el vicario y el condestable en perturbar la paz que gozábamos en esta plaza "y con lo que han hecho se acabarán de desengañar si yo tuve razón de echarlos de la Plaza o no" (Carta de 9/5/1702).

El 25 de mayo llegaba una gabarra cargada de leña y una semana después una saetía cargada de alimentos. Del Peñón le habían enviado una gabarra conducida por la galera San José para que les enviase agua, y en tres horas la tenía cargada, pero como iba en pipas que habían tenido vino, decía que se les corrompería en un par de días.

En la carta que escribía fechada el 13 de junio repetía las noticias que ya había dado en otra anterior referente a esos valencianos que se habían pasado a los moros, los cuales aseguraban al enemigo que podría tomar la plaza, con la ayuda de los de dentro, noticias que ahora también le comunicaba el gobernador de Málaga don Fernando de Argote, 
y volvía a señalar que había dado orden hacía ya muchos días para que no se pusiese a ninguno de guardia en los obras exteriores, sino en el recinto de la Plaza, y los tenía divididos en las guardias, por si querían intentar algo que no se encontrasen juntos. Si su majestad le enviaba la gente y municiones de guerra que le había solicitado en el correo pasado, si llegase el caso de que viniesen, tal como parecía ser por las noticias, el actuaría de manera que el rey se daría por satisfecho.

Tenía noticias de Oran de que el Turco, con un ejército de 20.000 hombres entre caballería e infantería estaba a seis leguas de la Plaza, que había juntado estas tropas con todos los alarbes del país y que estaba aguardando refuerzos, y que una vez le llegasen estos acabarían de demostrar sus intenciones. Continuaba excavando su mina, sacando de trecho en trecho unos ramales al Campo, con su hornillo, para estar prevenido si llegaban ${ }^{48}$.

A principios de julio avisaba al marqués que le habían llegado noticias con la embarcación que desde Alhucemas había mandado su gobernador, con el propósito de aprovisionarse de agua para el Peñón, de que se habían sacado de Mequínez siete cañones y dos morteros, y que se creía que eran para sitiar Melilla, y que así mismo había una gran cantidad de moros ocupados en abrir camino para pasar dicha artillería. Para comprobar estas noticias mandó hacer una salida a las posiciones de los moros con el fin de observar su reacción, y fueron tan pocos los que acudieron al arrebato, que no llegaron a cien hombres, de lo que deducía que los moros andaban ocupados en abrir los caminos de esa zona. Le habían llegado también noticias de que los moros de la parte del Peñón habían pedido al rey Muley Ismael que retirase al alcalde que tenían, pues les estaba ocasionando grandes gastos, que ellos mismos se encargarían de mantener aquel sitio. Así que mandó que se retirase y les dejase la artillería y un mortero y que pasase a Tetuán, y que luego fuese a Mequínez para darle órdenes del modo en que había de poner sitio a la plaza de Melilla. A la vista de estas noticias, le pedía al duque que insistiese ante su majestad para que se le enviase la gente y demás pertrechos que tenía pedidos, porque aunque en dos saetías que acababan de llegar le había llegado parte de lo que había solicitado, en cuanto a la munición de artillería tan solo le habían enviado 150 balas.

Las galeras que llevaban el correo oficial a Oran tocaron en ese

48 Carta de 13/6/1702. AHN. OSUNA, CT.36, D.12. 
puerto, por tener orden de los señores del Consejo para que se les entregasen cuarenta valencianos de los ochenta que había en la Plaza. Proseguía trabajando con mi mina y ramales, a trechos, para tenerlo adelantado como así mismo boy reparando algunas cosillas que son precisas, $\mathrm{y}$ haría muchas más cosas si su majestad le diese la providencia, o lo mandase al marqués de Villadarias o a don Fernando Argote, porque si las dirige don Juan Ginés de Cabrera, por la poca disposición que tiene, lo atrasa todo en lugar de adelantarlo. (Carta de 7/7/1702. AHN, OSUNA, CT.36, D.13).

En otra de sus cartas se quejaba al duque de la conducta del licenciado Manuel Galindo, que expulsado de los jesuitas, servía de vicario en la Plaza, el cual andaba mezclado en indecencias que en el más relajado seglar serían dignas de ejemplar castigo, del que había solicitado al obispo de Málaga que lo sacase de ella, y ahora andaba en la Corte explayando voces en su contra. A sus seguidores, que con componerse aquella guarnición de los peores de toda España, estos eran los peores de ella, los había apartado enviándolos a las Alhucemas y al Peñón. Iba sembrando en la Corte voces falsas e indignas contra su crédito, cuando todos los oficiales mayores de la Plaza y los eclesiásticos, incluso don Manuel, habían solicitado repetidas veces que lo conservasen en su cargo, y quizá por ello haciendo ya más de 16 meses que había cumplido su tiempo, se le mantenía en el cargo "tan contra mi salud y aumentos" (Carta de 7/7/1702. AHN, OSUNA, CT.36, D.14).

Había pasado don Domingo todo el mes de agosto en cama, aquejado de unas tercianas dobles, que lo habían dejado tan postrado, que aunque hacía unos días que se le habían pasado "no puedo volver en mí" (Carta de 16/9/1702. AHN, OSUNA, CT.36, D.15). Los días 18,19 y 25 de este mes habían llegado a Melilla los refuerzos solicitados, desembarcando en ella el Tercio del maestre de campo don Blas de Trinchería. En su viaje desde de España, las cinco saetías que lo transportaban, a causa de los vientos contrarios que les soplaron, habían tenido que detenerse muchos días en las Alhucemas, desde donde le llegó aviso de su gobernador con un barco a remo, que andaban faltos de agua para tanta gente, enviándoles por dos veces socorro, y ahora que habían llegado, volvía a enviar un pingue cargado de alimentos y agua a dicha Plaza, que había quedado muy disminuida de provisiones. Llegaba el Tercio "algo maltratado", por haber estado cinco meses embarcados, y decía, que si no se cuidaba de él, en lugar de recuperarse, se acabaría de perder, pues andaban medio desnudos.

El 27 de agosto había llegado desde Málaga el pingue de Nico- 
lás de Vizcaya, que venía cargado de alimentos. Durante la travesía se habían topado con una fragata de moros armada de cincuenta y tantos cañones, que andaba emboscada en una de las calas del Cabo, a tres leguas de la Plaza, que le salió al paso e intentó abordarlo por cinco veces, y de no haber tenido la dicha de venir embarcados en él unos oficiales que su majestad había mandado rescatar de la esclavitud en Argel, que se encontraban en Málaga, se hubiera perdido. Le habían llegado noticias de Tetuán y Mostagán que los piratas de estas dos plazas se habían acordado para venir al Cabo con algunas fragatas armadas, a ver si pillaban a las embarcaciones que viniesen a Melilla con bastimentos, pues ya que no podían tomarla por las armas, lo intentarían por hambre. Ya había dado aviso a Málaga para que las embarcaciones que se tuviesen que enviar fuesen las de mayor porte, y que viniesen bien armadas y pertrechadas y con gente de escolta a bordo, pero no había forma de que lo hiciesen, y si pasaba algún contratiempo no podrían quejarse de que no se les había prevenido, y en esta ocasión que había narrado habían tenido además la suerte de que se habían embarcado en el pingüe cuatro lombardas pedreras, con las que mataron a más de veinte hombres, teniendo nosotros tan solo un muerto ${ }^{49} \mathrm{y}$ cuatro heridos.

Del enemigo no había novedad ${ }^{50}$, tan solo le decía que le habían informado que estaban dejando que los holandeses e ingleses hiciesen almacenes en Tánger, y que la armada de estas dos naciones, con unas 170 velas, se había dejado ver por Cádiz, pero de esto último suponía que su excelencia estaría mejor informado.

Entre los refuerzos enviados, llegaba a la plaza el ingeniero segundo, capitán graduado (Cárdenas, 2005, p. 616), don Jerónimo Tortosa, que dispuso que se levantase una empalizada desde la mar de levante a la de poniente, avisando el gobernador de que si no se le enviaban las estacas que había pedido, no quedaría tan fuerte como era necesaria para defensa de ese frente. Había revisado la mina y ramales que se habían construido, dándolos por buenos, mandando que prosiguiese los ramales que se hacían desde la mina real.

Esteban Paterreyó, que murió de un balazo. MORALES (1995) p 92.

No habia novedad que destacar. Las muertes casi continuas que se producian en los constantes enfrentamientos con los moros, o a causa de disparos sueltos, en la situación que se encontró siempre Melilla, desgraciadamente no eran novedad. Ese tranquilo mes de agosto recoge Morales el fallecimiento violento de nueve individuos 
Vuelve a quejarse del abandono en que los tiene el asentista, y que a causa de ello ha tenido que parar nuevamente las obras porque le faltan picos, y están usando las llaves de mosquetes viejos para calzar los hornillos, y ya no podía ser mayor la miseria y desdicha en que estaban, y a los oficiales, viudas y huérfanos, en vez de atenderlos en sus necesidades, los tenía desesperados. "Yo no puedo creer sino que como él fue causa, en parte, de que se perdiese Larache, desea que se pierda esta Plaza" (Carta de 16/9/1702).

El 17 de septiembre llegaba a la Plaza una saetía cargada de alimentos y una faluquilla cargada con leña, que ya hacía once días que nadie comía de caliente. Se dio diez días de leña a la guarnición, y la demás se destinó al hospital, que estaba lleno de enfermos. Advertía que dada la presencia de ingleses en aquellas aguas, era conveniente que se buscase otro lugar distinto al de Málaga para el envío de socorros, pues cualquier día podrían tener un mal suceso. Las plazas del Peñón y Alhucemas andaban con falta de agua, y ya había tenido que socorrerlas ocho veces, que si no fuera por ello ya se habrían perdido. Vuelve a arremeter contra el asentista, al que achaca la falta de toneles que tienen en la plaza, pues paga poco al tonelero y no envía piezas para componerlos, y a causa de esta falta no había podido socorrer con más agua al Peñón.

A finales de septiembre, le confirmaba al duque las noticias que tenía de los almacenes que se estaban haciendo en Tánger para los ingleses y holandeses. Ali Venaudal, su alcaide estaba fundiendo, con los técnicos que estas dos naciones le habían enviado, muchas bombas y cañones. Le comentaba la noticia del desembarco que la flota angloholandesa había hecho el pasado 27 de agosto en Rota, y de la toma del Puerto de Santa María, "con vilipendio de las Armas Católicas" (Carta de 30/9/1702. AHN, OSUNA, CT.36, D.16), que tenía a toda la Andalucía en el último espanto, y que la mayor parte de la gente de milicias que iba acudiendo llegaba sin armas, "que es lo mismo que si no fuesen" (Carta de 30/9/1702), ataque que marcaría el principio de las acciones militares en la península entre borbones y austracistas. Le comentaba que el rey Muley Ismael les había ofrecido 5.000 caballos, y que se decía que era con el fin de que le ayudasen a tomar estos presidios. Como seguían sin llegar las estacas, hierros, y carbón, tenía parada las obras de la estacada y de los hornillos, con el peligro que ello suponía en caso de cerco. Enfadado arremetía otra vez contra el asentista, del que decía que nunca faltaba dinero para cobrar su sueldo, y que bien podía estar sin cobrarlo un año y enviar lo que tanto ellos necesitaban, que él ya llevaba cinco años y seis meses sin cobrar un maravedí. El 30 de septiembre 
llegaron al campo enemigo refuerzos de tropas de caballería e infantería y ese mismo día, por la noche, "nos atacaron hacia la parte que hacemos la estacada cubierta" (Carta de 30/9/1702).

Con la llegada del tercio de catalanes, ya va a disponer el gobernador de la gente que precisaba para llevar a cabo una salida con el propósito de castigar a los moros que desde el fuerte de la Huerta y posiciones que tenían junto al río, los andaban hostigando continuamente. La noche del 24 de mayo de 1703 salieron de la plaza 170 hombres del tercio, en tres columnas, al mando de los capitanes don Martín de Sagrera, don José Ferriol, y del alférez don Tomás Roquer, con el fin de ocupar posiciones ventajosas desde las que iniciar y proteger a la mañana siguiente el ataque, quedando amagada en la albarrada del Chinchorro el resto de las tropas que iban a participar en la salida, al mando de don Blas de Trinchería. Va a formar parte de estas tropas la compañía de dotación del capitán Bartolomé de Medellín, en la que irá de alférez Juan de Canal, sobrino del gobernador, que recibirá en esta acción cinco heridas y será recompensado con el nombramiento de capitán de una de dichas compañías de dotación de la plaza. Aunque costó que el enemigo respondiera al ataque, al final del mismo se les infringió un severo castigo, persiguiéndosele en su huida hasta el cerro de la Horca, pero viendo el gobernador que se adentraban mucho y quedaban expuestos a una emboscada, ordenó la retirada. "Fue muy divertida la retirada, porque unos soldados venían vestidos de moros despojados, otros con alfanjes desnudos, otros con caballos del diestro, otros con sillas y jaeces, muchos con lanzas, y todos alegres con la victoria" (Bizarrón, 170351). $\mathrm{Al}$ día siguiente desde el fuerte de la Concepción divisaron una nave que parecía de corsarios, y salió en su busca la fragata de la plaza llevando cuarenta hombres embarcados, al mando del capitán Bartolomé de Medellín. Tras navegar tras ella toda la tarde y noche la abordaron el día 26, apresándola y cogiendo prisioneros a quince moros, que serían vendidos como esclavos. [16]

Derrotado el enemigo y puestos en fuga los moros, Melilla recuperará cierta tranquilidad y el gobernador, que a finales del pasado año había suplicado nuevamente al duque que se acordase de él en el caso de que se ampliase el ejército de Andalucía, en octubre de 1703 cesaba en su cargo y pasaba a gobernar la plaza de Badajoz. Sabemos que en

Folleto que se publicaba en julio de ese mismo año 1703, según se recoge en PEÑA FAREL (1709), p. 514. 


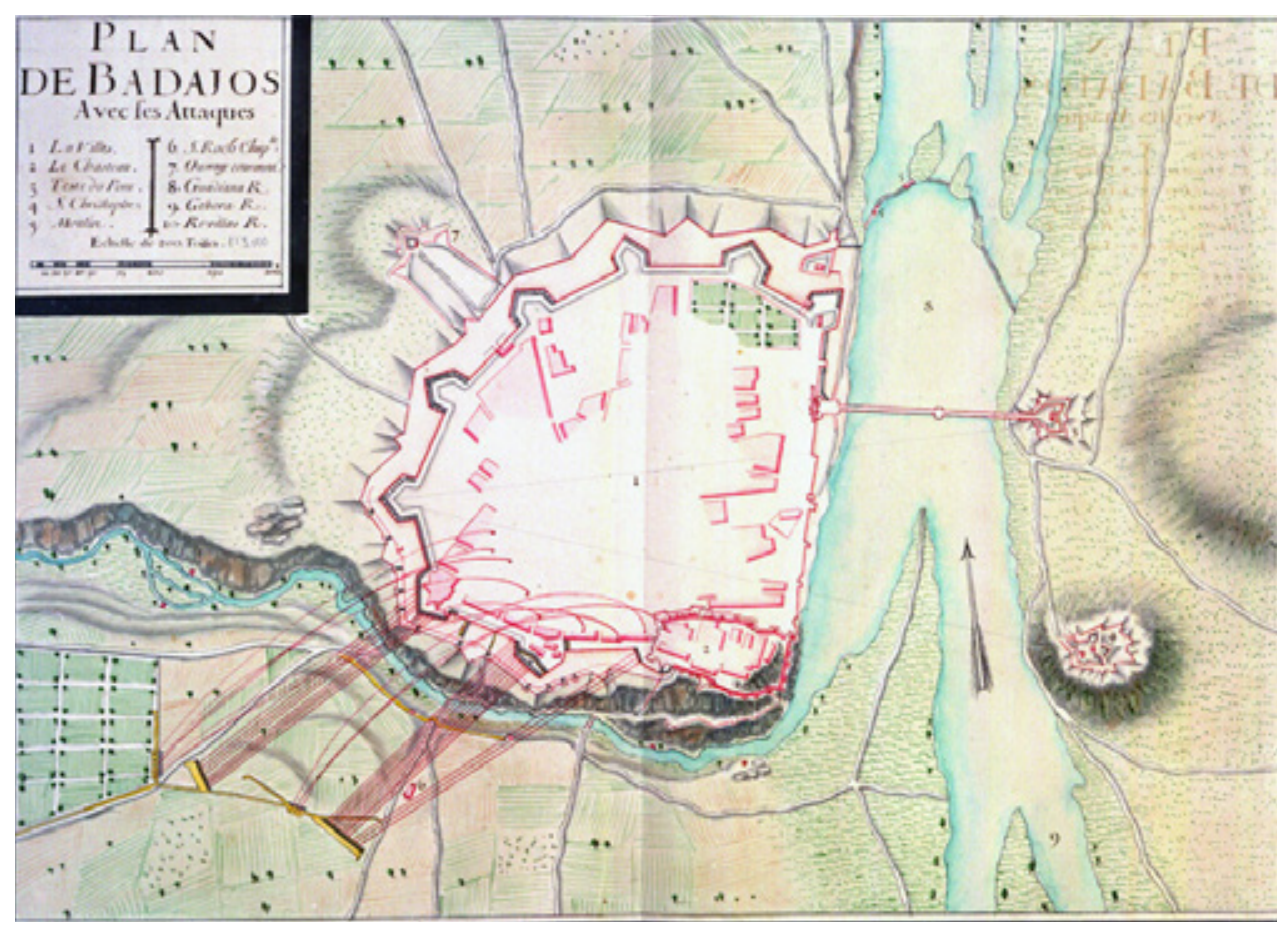

Fig. 16. La Plaza de Badajoz en 1705.

octubre de este año todavía estaba en Melilla, pues dicho mes compraba uno de los esclavos que se habían cogido en la presa del día 26 de mayo. Este esclavo que se llevó consigo a Badajoz, lo vendería el 26 de marzo de 1705 por el elevado precio de 5.250 reales de vellón (Periañez, 2013). Cuando los portugueses partidarios del archiduque Carlos sitian Badajoz el 1 de octubre, durante el asedio, enfermó don Domingo, siendo sustituido por el conde de la Puebla (Meléndez, 1705). En julio de 1707 se encuentra en Salamanca, desde donde avisa por carta al duque de Béjar que van llegando a esa ciudad las tropas procedentes de Francia, y que el marqués de Risburg había recibido noticias desde Galicia de que se había avistado al enemigo cerca de la frontera con 40.000 hombres $^{52}$. Ascendido a General, había llegado a esa ciudad con el cargo de Teniente General de las tropas que bajaron de Galicia (Cabezas, 1999). 


\section{Fuentes documentales}

Fuentes primarias:

Archivo de la Corona de Aragón (ACA):

Consejo de Aragón, Legajos, 0310, nº 067

Archivo General de Indias (AGI):

Contratación, 5440, N.2, R.161/ 5460, N.4, R.31/ 5791, L.1, F.4v

Indiferente, 121, N.114, N.166/ 122, N.50/ 123, N.47/ 124, N.108/ 125, N.76, N.159/ 126, N.63/ 127, N.25/ 134, N.57/ 135, N.200/ 139, N.18

Escribanía, 351B. Residencias de la Audiencia de Guatemala 1698-1709.

Audiencia de México 56, R.1, N.28

Mapas MP, México, 74/ 75

Archivo Histórico Nacional (AHN):

Nobleza. Ducado del Infantado. OSUNA. C.T.36, D1, D2, D3, D4, D5, D6, D7, D8, D9, D10, D11, D12, D13, D14, D15, D16, D17/ C.T. 102, D1, D7, D13.

Nobleza. Ducado de Béjar. OSUNA, CT, 36, D.17

Nobleza. Diversos- Colecciones, 175, N.10

La Gaceta Ordinaria de Madrid:

17/8/1677, p.31/ 14/9/1677 p.47v/22/3/1678, p.52/18/10/1678, P. 219v-220/18/10/1678/1/11/1678, p.232-232v/2/5/1679, p.89v-90v/ 13/6/1679, p.125v/ 14/11/1679, p.304.

\section{Bibliografía.}

ALCAIDE IBIECA, Agustín (1831) Resumen Histórico de las Resistencias de algunas plazas fuertes en los siglos XVI, XVII y XVIII, y parangón de aquellos sucesos con los dos sitios de Zaragoza. Tomo II, Madrid, p. 240

ARMENDARIZ, Sebastián. (1689) Noticias Extraordinarias del Levantamiento del Assedio puesto por los Moros a la Plaza de Melilla, cuyas particularidades se guardan con primero ocasión, y del ultimo considerable socorro introducido en la Plaza de Alarache, por disposición... Madrid

BAUER LANDAUER, Ignacio (1922). Papeles de mi archivo. Relaciones de África (Ceuta y Melilla) Tomo I, Editorial Ibero-Africana-Americana, Madrid p.37.

BIZARRÓN, Antonio (1703). "Señalada Victoria que por Mar y Tierra consiguió la Guarnición de Melilla contra los Moros, en los días 24 y 25 de mayo desde año de 1703, Madrid. En BAUER LANDAUER, Ignacio (1922). 
Papeles de mi archivo. Relaciones de África (Ceuta y Melilla) Tomo I, Madrid, p325.

BRAVO NIETO, Antonio \& FERNÁNDEZ URIEL, Pilar. (2006) "Melilla en los siglos XVI y XVII. El primer esplendor del Renacimiento y la grave crisis del Barroco". Historia de Melilla.

BRAVO NIETO, Antonio y otros (2009). Catálogo de Monumentos, Placas, Conjuntos Ornamentales y Heráldica de Melilla. Fundación Melilla Ciudad Monumental

CABEZAS FERNANDEZ DEL CAMPO, José (1999). "La guerra de Sucesión en Salamanca. La Alberca y Ledesma, 1707-1708”, Salamanca $\mathrm{n}^{\circ} 42$, Revista de Estudios

CARDENAS PIERA, Emilio de (2005). Índice Onomástico de la colección de libros del registro del Archivo General Miliar de Madrid, Ministerio de Defensa, Madrid, p.422

CORBALAN DE CELIS Y DURAN, Juan. (2011) "Algunos datos sobre Orán a través de la genealogía y las relaciones de servicios de algunos oraneses ilustres, gobernadores de la plaza de Melilla”, AKROS, 10

CORBALAN DE CELIS Y DURAN, Juan. (2014) "Unas notas sobre el gobernador de Melilla don José de Carrión y el comienzo del sitio de 1774", Trápana, 8

CORBALAN DE CELIS Y DURAN, Juan. (2015) "Unas notas sobre los Álvarez de Sotomayor y Antonio de Villalba, gobernadores de Melilla”, AKROS, 14

CORBALAN DE CELIS Y DURAN, Juan. (2016) "Los servicios del capitán Miguel de Perea en la armada de guarda de la flota de Indias", Aldaba, 40

CORREA DA FRANCA, Alejandro. Historia de la Muy Noble y fidelísima Ciudad de Ceuta, Ms.9741, Biblioteca Nacional de Madrid, p.207

ESTRADA, Juan Antonio (1798). Población general de España, sus reynos y provincias, ciudades, villas y pueblos, islas adyacentes y presidios de África, escrita por el pagador- Madrid, Tomo segundo, p. 554, 584

ESPINO LÓPEZ, Antonio (2000) “Oficiales catalanes en el ejército de los Austrias, 1635-1700", Cuadernos de Historia Moderna, 24, p.47

FERNANDEZ DE BUENDIA, Joseph, (1662) Relacion verdadera de lo sucedido a las catolicas armas de su Magestad, contra el Rebelde de Portugal por la parte de Ciudad-Rodrigo, gouernadas por el ... Duque de Ossuna ... Donde se dà cuenta de la toma de Escallon, y de todo lo sucedido desde ocho del mes de iulio hasta diez y nueue de Setiembre deste año de 1662. Madrid.

GASPAR ROIG Y ALPI, Juan (1678). Resvmen historial de las grandezas y antigüedades de la ciudad de Gerona y cosas memorables suyas eclesiásticas y seculares, assi de nuestros tiempos como de los passados, Barcelona 
MELENDEZ TEODORO, Álvaro (1705) "El sitio de Badajoz de octubre de 1705”. En SANCHEZ RUBIO, Carlos. (Coord.) (2010). Historia e Imagen de un asedio. Badajoz 1705, Badajoz

MORALES, Gabriel de (1995), Efemérides de la Historia de Melilla (1497-1913) Edición de MOGA ROMERO, Vicente \& BRAVO NIETO, Antonio. UNED, Melilla, pp.61,63; 77-78;

PEÑA Y FAREL, Narciso Feliu de la (1709). Anales de Catalvña y epilogo breve de los progresos y famosos hechos de la nación Catalana, de sus santos, reliqueas..., Tomo tercero, Barcelona.

PERIAÑEZ GÓMEZ, Rocío. (2013) "Una historia de esclavos en el Badajoz del siglo XVIII" Sharia, 72, Badajoz

POLO, Dominique (1986) "La vida cotidiana en Melilla en el siglo XVI" Criticón, 36, Toulose

RODRIGUEZ PUGET, Joaquín (1995), "El agua de Melilla, aljibes y pozos en los tres primeros recintos fortificados", Aldaba, 25, Melilla, p.111 